\title{
MORNING STAR RISING? INDONESIA RAYA AND THE NEW PAPUAN NATIONALISM'
}

\section{Peter King}

"Slavery, plunder, exploitation ... We have been thirty-five years alone . . " "*2

The future Information Minister and "intellectual general" associated with the Center for Strategic and International Studies in Jakarta, Brigadier-General Ali Murtopo, made a speech in 1969 to some of the 1,025 "representative" Papuans who were press-ganged into supporting the so-called Act of Free Choice which led to the official incorporation of West Papua into Indonesia. In the words of one of the 1,025 , as reported by a Dutch journalist:

Indonesia, as the strongest military power in Southeast Asia, is able to strike fear into any country. Jakarta [is] not interested in us Papuans but in West Irian as a territory. If we want to be independent . . . we had better ask God if he could find us an island in the Pacific where we could emigrate. . . 115 million Indonesians had fought for West Irian for years . . . they had made many sacrifices in the struggle and therefore would not allow their aspirations to be crossed by a handful of Papuans. Short shrift would be made of those who voted

\footnotetext{
${ }^{1}$ I would like to thank my colleagues-all of them-at the University of Kagoshima Research Center for the Pacific Islands for their generous help in the preparation of this article during 2000-01: Professors Noda Shinichi, Nakano Kazutaka, and Aoyama Toru, and also (not least) Ms. Kusumoto Hiroko. Theo van den Broek made an invaluable comment on an early draft, as did Danilyn Rutherford on two later ones. Chris Ballard, Richard Chauvel, and Richard Tanter helped substantially in various ways.

2 Wim Zonggonau, Remarks at the launching of the New South Wales State Parliament's Friendship Group for West Papua, Sydney, February 13, 2000. All of the starred $\left(^{*}\right)$ epigraphic quotations in the text derive from this source.
} 
against Indonesia. Their accursed tongues would be torn out. . . . Upon them would fall the vengeance of the Indonesian people, among them General Murtopo [Murtopo is quoted directly, speaking for himself] who would shoot people on the spot. ${ }^{3}$

The New Order had found its stride by 1969, and the violence predicted by Murtopo was to follow, if it had not already begun. "West Irian as a territory" was ruthlessly exploited by Suharto's government, with utter disregard for local feelings and interests. Virtually no benefits accrued to the Papuans, nor were they compensated for their loss of land to foreign and "crony" mining and timber companies or government-sponsored transmigration schemes. And as a result of both official transmigration and "spontaneous" immigration, the Papuans found themselves (together with their culture and their Christian religion) threatened with minority status in their own land within a single generation.4

The OPM (Organisasi Papua Merdeka) guerrilla and political resistance movement sprang up perforce to demand independence and challenge occupation by a ruthless plunderer, and a cycle of resistance and retaliatory repression began, which was to persist for more than a generation, right down to the collapse of the Suharto regime and the dawn of reformasi in Indonesia during 1998..$^{5}$ Among the still rather meager fruits of reformasi for West Papua has been the possibility to reflect publicly on the history of the Indonesian occupation: its slender benefits (mainly infrastructure development), as well as its costs, its losses, its tragedy, and the continuing pain:

We are victims of Indonesia; and others are too. But our feelings are like a needle penetrating our bodies. Only a good medical operation [i.e., Merdeka] can take out the needle. ${ }^{6}$

And so, in the democratic space opened up by reformasi for all Indonesians, and despite the rather erratic process of liberalization in Papua itself under Presidents Habibie and Gus Dur, the Papuans began their own collective historical summing up. It is a highly political exercise in which their burning historical grievance, now that they can express it freely, prompts a renewed, non-violent mobilization against the (purportedly reformed) occupier. The leaders of this grand exercise in collective revisionism have concluded and announced that the Papuan people were-and still are-victims of a three-cornered international konspirasi between Indonesia, Holland, and the United States in the 1960s to deprive Papua of its rightful sovereignty. From

\footnotetext{
${ }^{3}$ Link Van Bruggen, "Musyawarah and Deception," De Tijd (The Hague), August 14, 1969. Cited in Carmel Budiardjo and Liem Soei Long, West Papua: the Obliteration of a People (London: TAPOL, 1983), pp. 31-2.

${ }^{4}$ According to Willy Mandowen of Universitas Cenderawasih (UNCEN), Jayapura, the Indonesian government views the Papuans as "objects" because "they are a Melanesian-Christian minority in a Muslim country." Lindsay Murdoch, "Papuans riot after police kill seven," The Age, March 12, 2000.

5 See Robin Osborne, Indonesia's Secret War: The Guerilla Struggle in Irian Jaya (Sydney: Allen and Unwin, 1985).

${ }^{6}$ Woman delegate at the Mubes Papua 2000, Sentani, February 23, 2000. This and other details of proceedings at the Mubes, including quotation of speakers in this text, were gleaned by the author with the help of Clemens Runawery. The author was spontaneously accorded observer/participant status by the organizers of the Mubes, and was enthusiastically adopted in turn by three delegations (two native and one foreign) as mascot or better. However, in the early hours of what would have been Day Two of deliberations (February 24), he was warned off by the police.
} 
this perspective, the United Nations delivered the coup de grace to Papua when it finally endorsed the "Act of No Choice" (as the Papuans call it), even though its own officials on the ground in Irian had exposed the fraudulent and intimidatory "consultation" which led to the definitive incorporation of Papua into Indonesia, first as Irian Barat (West Irian), later (in 1973) as Irian Jaya (Victorious Irian). ${ }^{7}$

This "conspiracy" finding figures prominently in the documentation of the two landmark political assemblies convened in Jayapura (or Port Numbay, as many Papuans would now have it) in the name of the independence movement during the first half of the year 2000. The first assembly was the Mubes (Musyawarah Besar, grand consultation) Papua 2000, which was held from February 23 to February 26 in Sentani, Jayapura. It repudiated the Act of Free Choice in ringing terms and elected a Dewan Presidium Papua (Papua Presidium Council, PPC) with a mandate to organize the second event, a Kongres Rakyat Papua II, by May 1. There was a delay, and the Second Papuan People's Congress was actually held from May 29 through June 4 at UNCEN (Universitas Cenderawasih) in Abepura, another satellite town of Jayapura. Representatives at this second gathering-notional heir and successor of the Dutchsponsored New Guinea Council (Nieuw Guinea Raad) of 1961-2 (the first Congress)announced that Papuans had been independent since the meeting of the New Guinea Council on December 1, 1961, a meeting at which the Morning Star flag was raised for the first time (alongside the Dutch flag) in the capital, Hollandia. Papua would no longer recognize Indonesian rule. This was the message to be digested by the world, for which the Papua Kongres leaders shortly found themselves facing treason charges.

This article will attempt a critical overview of the new post-reformasi phase of the West Papuan struggle for self-determination, and attempt to answer several key questions of interpretation, evaluation, and praxis along the way:

1) What should we understand by Papuan nationalism, and what has sustained and shaped it since its origins in the Pacific War?

2) How and why did the new post-reformasi "civilian" national movement emerge?

3) What are the real strengths and weaknesses of this movement, which claims to represent all Papuans and to have a solid, representative social basis. Are its leadership and strategic orientation soundly conceived?

4) What role can the OPM play in the future national struggle, and can its uneasy and competitive relationship with the Presidium of the Papua Council be transformed into some kind of working united front?

5) What has been the overall political impact of renewed military, police, and judicial repression in Papua since the weakening of the Gus Dur presidency from mid-2000?

6) Can the new law of November 2001 defining special autonomy for Papua turn back the tide of Papuan nationalism flowing against Jakarta?

7) Is Papua still faced with a realistic prospect of "creeping genocide" from the impact of settled Indonesian transmigrants, traders, and bureaucrats, and new

${ }^{7}$ John Saltford, "United Nations Involvement with the Act of Self-Determination in West Irian (Indonesian West New Guinea) 1968 to 1969," Indonesia 69 (April 2000): 71-92. 
"spontaneous" immigrants, now that New Order style official transmigration has been suspended? Or is there, on the other hand, a prospect of Indonesian settlers actually identifying with and supporting the Papuan cause in significant numbers?

8) In view of the new prominence of the Papuan self-determination issue internationally, is there a realistic prospect of merdeka (freedom) for West Papua in the foreseeable future?

\section{"I like the Indonesians ... It's the system I hate"*: Papuan Nationalism Year 2002}

Papuan nationalism had come a long way since its first stirrings in the great Koreri "cargo" movement that spread throughout the Biak region during 1938-43; this movement had been directed variously against occupying Dutch, invading Japanese and, significantly, "Amberi." (Amberi was the Biak term for non-Papuan "Indonesiansto-be," most of them from Ambon in the neighboring Moluccas, who had served the Dutch as teachers, missionaries, and officials, and were also inclined to collaborate with the Japanese..$\left.^{8}\right)$ Following the onset of the Indonesian revolution and the return of the Dutch after the Pacific War, Papuan proto-nationalism split into two streams: some Papuans tried to follow Indonesian cues, while others followed the Dutch, and still others tried to straddle or coordinate the two. The idea that Papuan patriotism, as it slowly transcended its micro-ethnic "tribal" origins, ${ }^{9}$ could find fulfillment in Indonesia Raya was, of course, primarily a ruling Indonesian idea. Ironically, it was Indonesian behavior that ultimately killed it, and, with it, the "Indonesian" in almost all Papuans, but before that happened, there were pro-Indonesian leaders in serious political contention under the Dutch. They were particularly strong around Sorong on the north coast of the Bird's Head and on Biak and Japen islands in Geelvink (Cenderawasih) Bay. Although the most prominent of them, Silas Papare, was himself in exile in Jakarta during the 1950s, his followers in Serui on Japen and their Partai Kemerdekaan Indonesia Irian were a thorn in the side of the Dutch right down to $1962 . .^{10}$

Papare was among the Papuan "fighters for independence" who supported Sukarno's Trikora (three commands) to liberate the province, which was issued on December 19, 1961. A small legion of Papuan public servant collaborators/ cooperators/cooptees (it is often not clear what we should call them) played active roles in Irian thereafter. Outstanding Papuan personalities served in the military (for instance, Seth Rumkorem), the governor's office (Elizer Bonay), the civil service (Dr.

\footnotetext{
${ }^{8}$ Freerk Ch. Kamma, Koreri: Messianic Movements in the Biak-Numfor Culture Area (The Hague: Martinus Nijhoff, 1972), Chapter VIII. See also Danilyn Rutherford, "Waiting for the End in Biak: Violence, Order and a Flag Raising," Indonesia 67 (April 1999): 45, 54; and Jan Pouwer, "The Colonisation, Decolonisation and Recolonisation of West New Guinea," The Journal of Pacific History 34, 2 (1999): 166. The term "Amber" is now used in Papua to refer to any Indonesian settler.

${ }^{9}$ From one Melanesian perspective, "tribal" identity is a "kickstart for West Papuan nationalism." Otto (John) Ondawame, "West Papuan Nationalism and the Organisasi Papua Merdeka (OPM)/Free Papua Movement: One People, One Soul" (PhD dissertation, Australian National University, 2000), p. 39 ${ }^{10}$ Richard Chauvel, "Decolonising without the Decolonised: the Liberation of Irian Jaya," in Las Relaciones Internacionales en el Pacifico: Colonizacion, Descolonizacion y Encuentro Cultural, ed. Delores Elizalde (Madrid: Consejo Superior de Investigaciones Cientificas, 1997).
} 
Thomas Wanggai), and the local provincial parliament (Chief Theys Eluay). But proIndonesian Papuan nationalism more or less died with Indonesia's "locust" occupation in 1963, as most of the sincere and willing collaborators began to feel betrayed. Already the OPM had emerged from the widespread and determined revolt of the Arfak people around Manokwari in 1965.11 Even "official" Papuans began to develop a root-and-branch critique of the Indonesian occupiers, which foreshadowed their steady, predictable defection to the nationalist camp, and their subsequent persecution. (All of the outstanding individuals named above migrated eventually into the independence movement, and thereafter to the jungle, to jail, to exile, or all three.) The movement was never unified or even united, but it was held together by a core nationalist mood and set of symbols associated with the OPM, and by near-universal identification with its goals, even among illiterate Papuans, who made up 30 percent of the population. So far the only serious challenge to the OPM symbology has come from a source potentially even more threatening to the brown mastas of the Red and White ${ }^{12}$-that is, Thomas Wanggai's West Melanesia movement. (Wanggai's movement still persists, and represents an explicit quest for solidarity with the Eastern Melanesians of Papua New Guinea and beyond. ${ }^{13}$ )

\section{"We are all OPM"}

Benedict Anderson suggests that Irian became "imaginatively incorporated" in the Indonesian republic of 1945 in ways that East Timor never was, and perhaps could

11 Osborne, Indonesia's Secret War, p. 35.

$12 \mathrm{cf.} \mathrm{"White} \mathrm{mastas"-} \mathrm{Australian} \mathrm{colonial} \mathrm{officials} \mathrm{in} \mathrm{the} \mathrm{"other"} \mathrm{Papua} \mathrm{and} \mathrm{New} \mathrm{Guinea.} \mathrm{"Red} \mathrm{and}$ White"-Mera Putih: the Indonesian national flag.

${ }^{13}$ See Benny Giay and Jan A. Godschalk, "Cargoism in Irian Jaya Today," Oceania 4 (June 1993): 338-40. See also George Aditjondro, "Bintang Kejora di Tengah Kegelapan Malam: Penggelapan Nasionalisme Orang Irian dalam Historiografi Indonesia" (The Morning Star in the middle of darkest night: the mystification of West Papuan nationalism in official Indonesian historiography), in his Cahaya Bintang Kejora: Papua Barat dalam Kajian Sejarah, Budaya, Ekonomi dan Hak Asasi Manusia (The Beam of the Morning Star: West Papuan Studies in History, Culture, Economics and Human Rights) (Jakarta: Lembaga Studi dan Advokasi Masyarakat, 2000). Aditjondro argues that a broad Melanesian consciousness was first expressed in Thomas Wanggai's movement.

Strolling on the outskirts of Biak town during the early months of the Gus Dur presidency (February 2000), I happened on two striking images of the West Papuan quest for freedom. First, in a sububan front yard opposite the airport, Papua New Guinea's national flag was prominently displayed alongside the Morning Star flag (Bintang Kejora), a reminder to the passer-by of the late Dutch days, when people imagined that a liberated Australian Papua and New Guinea might unite with a liberated Dutch Nieuw Guinea to create a Melanesian federation. Second, a large and handsome outrigger canoe, pulled up on the beach nearby, had been vividly painted all over in the American Stars and Stripes, code, I was told, for the Bintang.Kejora, but also a "cargo" symbol from the 1940s, when the mere passage of a few American soldiers through Biak waters could cause a sensation. Kamma, Koreri, p. 189.

The Morning Star flag was originally raised in Jayapura by Thomas Wanggai on December 14, 1988. It had been sewn by his Japanese wife, who was also jailed for her trouble. It featured fourteen stars to symbolize West Melanesian districts-to-be, plus colored bars for Melanesianism (black), bravery (red), and holiness (white). It thus rejected the pagan Koreri derivation of the single Morning Star-and also its Dutch associations.

Fifty demonstrators attempted to commemorate the original flag raising and proclamation of a free West Melanesian state in Jayapura (Port Numbay to Papuan nationalists of all stripes) on December 14, 2000. Five were arrested. Jakarta Post, December 15, 2000. 
never be. According to Anderson, the Indonesians "sincerely regard [the Papuans] as brothers and sisters," especially because the national language, Bahasa Indonesia, is also the lingua franca of the province (home to 250 tribal languages). ${ }^{14}$ Moreover, he says, certain Irianese sports and entertainment stars are seen as unambiguously Indonesian. ${ }^{15}$ Anderson believes that only a "quasi-nationalist resistance" exists in Papua, ${ }^{16}$ although he does not say precisely why he thinks so. In early 1999, Anderson argued that "genuine and full autonomy" for Irian (and Aceh) would cause "separatist movements to lose their steam" and then "Irianese . . . will once again be invited seriously back into the common project and the deep horizontal comradeship from which they should never have been excluded."17

The Acehnese may have been invited into the nation-building project (and enjoyed the comradeship with their Indonesian sisters and brothers), but the Papuans (if one discounts the cosseting of those few in exile in Jakarta before 1962) certainly never were: there is no question of the Papuans being invited back. ${ }^{18}$ Repression can cross a line where, short of genocide or demographic inundation, rule by a government perceived to be both foreign and intolerable can never restore legitimacy in any time frame meaningful to the generation that is suffering from such rule. The mere attempt by the occupier to retain power vitiates the attempt to legitimate it. In the Indonesian case, we can now see (if we could not before) that the government has been virtually incapable of reform since the collapse of Suharto's New Order, and it is invidious to hold the Papuans hostage inside Indonesia by asking them to trust in a supposed capacity for meaningful reform which simply does not exist.

Certainly television viewers in Jakarta may imaginatively incorporate Irian into the nation, but for Indonesians on the ground, in the province, another mode of perception prevails. Indonesians in Papua see "Papua bodoh" - stupid Papuans; backward Papuans, especially highlanders; ungrateful Papuans; treacherous, wild terrorist and "secessionist" Papuans ... aliens, in a word. ${ }^{19}$ And this ruling official perception is

14 Benedict Anderson, Imagined Communities: Reflections on the Origins and Spread of Nationalism (London: Verso, Revised edition, 1991), p. 177.

15 “No matter how badly Irianese may actually be treated in Irian itself, for Indonesians as a whole they are part of 'us'." Benedict Anderson, "Imagining East Timor," Arena Magazine 4 (April 1993).

16 Ibid.

17 Benedict Anderson, "Indonesian Nationalism Today and in the Future," Indonesia 67 (April 1999): 5. In referring to "Irianese" here, Anderson falls into a trap of his own devising-he has just condemned Suharto's "Dry-Rot Order" for naming the people of Irian after the province. Actually "Irianese" remains a useful term for the whole (indigenous and settler) population of the province, but Anderson is clearly discussing (indigenous) Papuans.

18 Benedict Anderson's history can be faulted on its details too. "The OPM," he says categorically, "arose not before the Orde Baru ... but afterward." But, as I have suggested above, the OPM was arguably born during or before the Manokwari uprising against the occupying forces of Orde Lama in July 1965, two months before Gestapu (September 30,1965), when Suharto seized power, and seven months before Supersemar (March 11, 1966), when Sukarno finally yielded to him. See Osborne, Indonesia's Secret War, p. 35; Ondawame, "West Papuan Nationalism," p. 93; 'DB, "Unravelling the history of the OPM," Tempo Magazine 29,46 (January 16-22, 2001).

${ }^{19}$ Following the interrogation, beating, and torture of students arrested after the OPM guerrilla attack in Abepura on December 7, 2000 (discussed below), witnesses reported these police statements: "Your mother eats pig and you have the brains of a pig... Even with your college degree you won't get a job ... You Papuans are stupid; stupid and yet you think you can be independent ... You put your hopes in a guy like 
reciprocated by the Papuan subjects. The Papuans who truly identify themselves as Indonesians are an almost vanished breed, and even those who seemingly do are frequently to be heard saying that one more example of neglect, atrocity, scorn, disregard, or exploitation will push them off into the autochthonous nationalist camp. ${ }^{20}$ The reality is that Indonesia, and even Indonesians generally, figure all too often as the Demonized Other among the Papuans. Thus, for instance, the Papuan intelligentsia tends to show little discrimination or respect when assessing the achievements of the Indonesian revolution and its fifty- (seventy?) year-old ostensible project of multi-ethnic, multi-religious, multi-cultural, quasi-secular, and democracyminded national integration. On the contrary, for many Papuans "Indonesia" tends to symbolize anti-Melanesian racism, Islamic intolerance, and an Asian superiority complex. There is also a Papuan tendency to single out Java and the Javanese (as well as Islam) for special excoriation, ${ }^{21}$ even though the worst "hands on" tormentors of Papua may well have been (Christian) Bataks in the Indonesian military command. ${ }^{22}$ (In fact, many Papuans have helped traumatize the region, including, perhaps most notoriously, Biaks and other "coastals" serving in the army and as police in the highlands.)

Among the group of apparently willing collaborators with Jakarta in the early years of occupation, two of those already named stand out-the man who was probably the OPM's most important military-political leader, Seth Rumkorem, and the man who became the chairman of the expanded Papua Presidium Council that emerged from Kongres Papua, Chief Theys Hiyo Eluay. Willing collaborators of their caliber or potency are a practically extinct species today. Long before the fall of Suharto, incumbent Irianese governors wishing to preserve a modicum of legitimacy among the people often echoed the chorus of complaints by the OPM and overseas dissidents about rule from Jakarta, as I have said. They are on record frequently deploring

Tom Beanal who knows nothing." When one student cried out, "Jesus," a policeman responded, "Your God Jesus is dead." Cited in Human Rights Watch, Violence and Political Impasse in Papua (New York: Human Rights Watch, July 2001).

20 Interview with Elias Papindrey, Jakarta Post, July 27, 2000. Papindrey was jailed by the Dutch and served as Deputy Governor from 1977-82.

21 Ondawame, "West Papuan Nationalism," Chapter 2. Former OPM "Minister of Defence," John Otto Ondawame, develops at considerable length the argument that the Java-dominated "artificial nation-state" of Indonesia practices "internal colonialism." He insists that the West Papuans share "a common culture... and common racial characteristics with the other Melanesians who have qualified for nationhood," and that this culture and these characteristics sharply distinguish them from "the Indonesians," and, of course, entitle them to a nation and state of their own (pp. 49-50). Kei islanders and others in Maluku might be puzzled by this claim, and Christians throughout Eastern Indonesia might question his assertion that "religion" also distinguishes Papua from the rest of the country (p. 43), but most Papuans (including even the Papuan Muslim minority centered around Fak Fak and Sorong) would agree with him.

22 Major General Mahidin Simbolon was appointed in January 2001 to be the Kodam VIII Trikora commander in Jayapura. Major Simbolon was a Christian Batak, a veteran of Kopassus operations in Timor, and a member of Prabowo Subianto's circle. His name has appeared on a list of officers recommended for further investigation in connection with TNI (Indonesian armed forces) crimes in East Timor. See James Dunn, Crimes Against Humanity in East Timor: January to October 1999: Their Nature and Causes (Dili: UNTAET), p. 19. Dunn's report was written at the behest of the Prosecutor General appointed by UNTAET, the UN Transitional Administration in East Timor. See also Douglas Kammen, "Papua based TNI Officers," unpublished paper, 1999. The message to West Papuans in Simbolon's appointment was clear. 
Indonesia's vandalistic exploitation of the province's resources and also the "demographic aggression" (as it might be called) that resulted from the transmigration program and the influx of Buginese, Butonese, and Makassarese traders from South and Southeast Sulawesi, who established a stranglehold on Papua's urban economy. The governors also sometimes even deplored the actions of the police and military for carrying out brutal repression with impunity.

The number of "official" Papuans who now unequivocally defend or support the Indonesian regime as it exists in the province is very small, and, indeed, during Kongres Papua, even the acting non-Papuan governor of Irian, Musiran Darmosuwito, apparently threw in his lot with the Kongres's leadership, at least for a while. Musiran, together with the chairman of the Irian Jaya legislature (DPRD, Dewan Perwakilan Rakyat Daerah), T. N. Kaiway, attended the closing ceremony of the "treasonous" Kongres after representatives had made their "declaration of non-integration," and later went on record saying it was too late to deny Papua independence. ${ }^{23}$ The official bureaucracy has long been home to secret or not-so-secret OPM supporters and other patriotic "secessionists," including Dr. Don Flassy, one of the Presidium leaders destined to be arrested in November 2000.24 However, even a pacifist patriot like Benny Giay is exasperated by those bureaucratic Papuans (including a group at UNCEN), whom he calls "spiritual Indonesians." He says that they are closed to new ideas and too eager to claim that they "have to follow the waves" rolling out from the center. ("This is what Jakarta wants" defines their agenda, he says.) According to Giay, these bureaucrats dominated the Papuan attempt to draft a "special autonomy" status for the region that would actually have been far more radical than the "ordinary" autonomy status Jakarta granted to all provinces on January 1, 2001. ${ }^{25}$ As

23 "W Papuans declare independence from Indonesia," Jakarta Post, May 6, 2000. Indeed, all members of the provincial Muspida (Musyawarah Pimpinan Daerah, governor's advisory council) attended the opening session of the Kongres. Participants included the chairman of the Muspida, who is the Panglima (military commander), as well as the deputy governor, the rector of Universitas Cenderawasih, and the Kapolda (police chief).

${ }^{24}$ As a senior civil servant on the provincial development planning board, Flassy was able to help "validate" the occupation of the Irian Jaya Arts Center building in Jayapura by the Presidium's militia (Satgas Papua: Satuan Tugas Papua, Papua Taskforce) and its officially sponsored ex-OPM veterans, until a police crackdown in December 2000 ended that occupation.

25 Telephone interview, February 28, 2001. Benny Giay withdrew from the special autonomy drafting group (Team of Fourteen-later Team of Ten) formed by the UNCEN rector on behalf of the Papuan governor. By his withdrawal, Giay meant to protest the group's alleged failure to consult widely or address wider Papuan concerns. At least one other non-UNCEN academic member of the Team of Fourteen, however, has strongly defended the draft finally presented to Jakarta by the Papuan governor, Jap Salossa. See Agus Sumule, "Local Communities, Logging Companies, and Conservation Organizations in West Papua/Irian Jaya," paper presented at the Conference on Resource Tenure, Forest Management and Conflict Resolution: Perspectives from Borneo and New Guinea, Australian National University, April 911, 2001.

Franz-Albert Joku, International Moderator of the Papua Council Presidium, claims that the special autonomy proposals drafted by the Team of Fourteen reflected the influence of Kongres Papua on Governor Salossa and others, even though the Dewan Papua Presidium has always officially distanced itself from the draft and the whole quest for a generous special autonomy deal. He cites as evidence the proposals' demand for a kind of quasi-independence: according to the draft, the governor, vice governor, and all members of a new bicameral local parliament must have at least one Papuan parent, for instance, and the provincial government is to control immigration and the police. Interview, Sydney, June 8, 2001. On the autonomy draft see also "Papuan proposals seek wide-ranging autonomy," Jakarta Post, April 27, 2001. The full text (which 
it happened, the draft actually adopted by the DPR (Dewan Perwakilan Rakyat, People's Representative Assembly) in Jakarta fell well short of "official" Papua's proposals and was promptly denounced by Papua Presidium leaders. There is little doubt that at least some of the "spiritual Indonesians" on the governor's team were inclined to advocate Papuan independence. ${ }^{26}$

By my observation, the number of Papuans who actually regard themselves as Indonesians is extremely small, and, reciprocally, the number of non-Papuan Indonesians within the province who regard the Papuans as fellow citizens-fully, not just legally-is minute. However, since President Gus Dur renamed the province "Papua" when he came to celebrate New Year 2000 and Indonesia's legislature finally confirmed the name in its special autonomy package, approved November 2001, there is a nice irony in the fact that while Papuans, however reluctantly, are still "Indonesians," real Indonesians (i.e., settlers from other provinces) are now also "Papuans."

Indigenous Papuans still identify, by and large, with the OPM resistance, which Indonesian officials for thirty-five years have stigmatized as a guerrilla organization composed of "wild terrorist gangs," or, less colorfully, as an "unauthorized agitational movement" (GPL, Gerakan Pengacau Liar). Thirty-five years of forceful integration have produced a wall of incomprehension and resentment that divides the indigenous from the immigrant communities in Irian itself. The immigrants are now becoming as worried about their future as the indigenous Papuans. Even so, personal relations between Papuans and Indonesians are, on the whole, surprisingly cordial; some settlers now fully identify themselves with the interests of Papua and the Papuans, as I shall suggest below, and the independence leaders have been at some pains to reassure the immigrants about their future welcome in an independent Papua.

The new "civilian" Papuan national leadership and the partially compromised Papuan officials, alike, must deal with a popular mood that demands eventual independence. Thus, even though the current post-Kongres leadership has serious shortcomings, the people themselves tend to stand firm to prevent their leaders from backsliding on the independence issue. Since the onset of reformasi, and until his recent murder, the leading proponent of defiance and independence was Theys Eluay. His history is instructive in this context, for before 1998 he was a prominent supporter of Indonesian rule and an active New Order bureaucrat, as well as a traditional chief of the Sentani tribe, who became head of the government-sponsored province-level tribal organization. He was also an official participant in the forcible incorporation of West New Guinea into Indonesia (one of the notorious 1,025) and a Golkar Party deputy in the Irian DPRD for fifteen years, beginning in 1977, during which time he supported the

exists in many draft versions) takes the form of a draft law to be passed by the DPR in Jakarta, and is entitled "Otonomi Khusus bagi Propinsi Papua dalam Bentuk Wilayah Berpemerintahan Sendiri" (Special Autonomy for the Province of Papua in the form of Regional Self Government), Jayapura, 2001. It has been translated into English by Agus Sumule, who was also the principal author of an authoritative background paper on the draft law put out by the governor's team: Gist of Thoughts Forming the Background of the Composing of the Bill on Special Autonomy for Papua Province in the Form of a Self-governing Territory (Jayapura, 2001).

26 See "Special Autonomy for Papua," Jakarta Post, October 26, 2001. Statement Issued on October 20, 2001 by the Papua Presidium Council, Kabar Irian, October 25, 2001. 
transmigration program while criticizing the failure of the government to consult "tribal leaders" when it seized people's land. ${ }^{27} \mathrm{He}$ naturally acquired a reputation for close collaboration with the occupier and even for identifying OPM supporters to be targeted by the military. After the fall of Suharto in May 1998, however, he made a spectacular conversion, offered a public apology for his dark past to the nationalist camp ("Then I was Saul; now I am Paul"), and almost at once became a leader to reckon with. ${ }^{28}$ His murder in November 2001, almost certainly by the security forces, may have removed many doubts about his standing as a Papuan patriot. ${ }^{29}$

The other outstanding leader of the post-Suharto period has far more solid nationalist credentials than Eluay, credentials established through active political resistance against the New Order. Tom Beanal, like Eluay, has been and still is an important traditional chief-of the Amungme tribe. The Amungme were the principal victims of the huge Freeport copper and gold mine at Tembagapura in the southern highlands of Mimika regency. Through LEMASA (Lembaga Musyawarah Adat Amungme, Amungme Tribal Consultative Council), based in the lowland mining town of Timika, Tom Beanal and others waged a protracted struggle against the Freeport mine and even launched a US $\$ 6$ billion damage suit against Freeport McMoRan Copper and Gold in American courts. A deeply embarrassed company managed to abort the case, but Freeport has since become remarkably responsive to local demands, and Beanal himself is now a commissioner of PT Freeport Indonesia.

Beanal emerged as a national leader and appears to be Eluay's likely successor as chairman of the Papua Presidium Council. It was he who led the so-called Team of One Hundred (Tim Seratus) to the Bina Graha presidential palace in Jakarta on February 26, 1999. There, in the name of initiating "national dialogue" on the future of Irian Jaya, he delivered a peremptory demand for independence to then-President Habibie and other assembled cabinet ministers. This declaration created shock in Jakarta and euphoria all over Papua. At the Mubes in February 2000, "Theys/Tom" emerged as joint chairmen of the Papua Presidium Council elected by the delegates, and thus as the ruling duumvirate of the stateless, but militant, nation of Papua.

However, both had continuing problems with the people and also with each other. Eluay actually threatened to resign from the chairmanship of the Papua Presidium Council under rather mysterious circumstances late in 1999, but there was a spontaneous popular backlash against such a move (which it was perhaps his intention to provoke). ${ }^{30}$ Both Theys Eluay and Tom Beanal also had local-level

27 "Golkar considers dismissing Irian J legislators," Jakarta Post, August 7, 1997; "Govt knows how to win Irianese tribal hearts," Jakarta Post, August 19, 1996.

28 Interview, Franz-Albert Joku, Sentani, February 23, 2000. In a long explanatory interview with the Cenderawasih Pos in November 1998, Theys offered this explanation of his actions: "How could we fight before? We had nothing in our hands... If we fought we would have been finished. Now everything is different." Cited in Vaudine England, "Hush as "Great Leader' arrives in person," South China Morning Post, October 23, 2000. Of course, the OPM had been fighting, spears and bows in hand, for thirty-three years by this time.

${ }^{29}$ For the Presidium reaction to the murder of Theys Eluay on November 10, 2001, see Presidium Dewan Papua statement, TAPOL. Kabar-Irian, November 14, 2001.

30 Interviews, Theo van den Broek, Jayapura, February 25, 2000; and Franz-Albert Joku, Sydney, June 8, 2001. 
legitimacy problems: other Sentani chiefs, mindful of Eluay's past, refused to accept his leadership, and the Amungme and Papuan immigrant communities in Timika variously criticized Beanal for having sold out to Freeport or for being too scared to visit his own homeland. Beanal had failed to appear in Timika for many months following a disastrous Morning Star flag-raising episode there in late 1999, which TNI (Tentara Nasional Indonesia, Indonesian armed forces) may have sponsored. ${ }^{31}$ In fact, Tom Beanal had serious reservations about Eluay's strategy of pushing forward with a declaration of independence at the risk of a serious clash with Jakarta, but these were apparently overcome at the Kongres, not only by Eluay's stronger personality and strong-arm tactics (see below), but again by the demotic factor-the people were not disposed to accept less. Beanal and many others also had serious reservations about Eluay's past ties with the military and the Golkar Party. The fear is that he was the "residual New Order" choice for Papuan leader precisely because of his past and the expectation that he-and, through him, the Papuan people-could be ultimately controlled from Jakarta. ${ }^{32}$

It is known that much of the money supporting Theys Eluay as he campaigned for independence came from tainted sources. Yorris Raweyai is a native-born half-Chinese from Serui and an intimate of Eluay's from the New Order days. He is also a gang leader and hit man, chairman of the disgraceful Golkar Party youth organization, Pemuda Pancasila, and a crony of Suharto's middle son, Bambang. ${ }^{33}$ In 2002, he was still facing criminal charges in Jakarta for his role in the brutal assault on the headquarters of Megawati Sukarnoputri's PDI-P (Partai Demokrasi IndonesiaPerjuangan, Indonesian Democratic Party of Struggle) party headquarters in 1996. Nevertheless, his ties to Eluay were strong. He was the external (Jakarta) representative of Eluay's LMA (Lembaga Masyarakat Adat, Foundation for Customary Society or Association of Traditional Peoples), the "peak" governmentsponsored tribal council for Papua, and his seat on the Papua Presidium itself is probably secure while New Order money still flows through him to the movement. ${ }^{34}$

There was not much other money available during the early stages of reformasi. It is true that President Gus Dur not only initially approved of Kongres Papua and agreed to open it-an offer later withdrawn-but he also subsidized the Kongres with a

31 Interview, Father Bert, Tiga Raja (Three Kings) Church, Timika, February 27, 2000. Tom Beanal was reported in Timika again on August 21, 2000, when he announced that "We [the Papua Presidium Council] and all the Papuan people are ready to wage war against Indonesian militarism to the last drop of our blood." Agence France Presse, Jakarta, August 21, 2000.

32 Telephone interview, Benny Giay, February 28, 2001.

33 See George Aditjondro, "Guns, Pamphlets and Handie-talkies: How the military exploited local ethnoreligious tensions in Maluku to preserve their political and economic privileges," in Violence in Indonesia, ed. Ingrid Wessel and Georgia Wimhofer (Hamburg: Abera Verlag, 2001), p. 110.

34 On Yorris, see also Human Rights Watch, "Indonesia: Human Rights and Pro-Independence Actions in Papua, 1999-2000," Human Rights Watch 12,2 (May 2000), Section IV: 4; and Marianne Kearney, "Gangsters for Suharto are eclipsed by New Age thugs," Straits Times, November 26, 2001. See also Loren Ryter, "Pemuda Pancasila: The Last Loyalist Free Men of Suharto's Order?," in Violence and the State in Suharto's Indonesia, ed. Benedict Anderson (Ithaca, NY: Cornell Southeast Asia Program, 2001), pp. 124155. Yorris says Pemuda Pancasila is now reformed, interested in social welfare, and "like the Greenpeace of Indonesia." He is apparently popular with many Papuans in Jakarta for helping out in times of trouble. 
government donation of one billion rupiah (US\$120,000). ${ }^{35}$ However, this generosity was never going to be repeated once the Kongres organizers faced treason charges. So Yorris's money was welcome to many, and his leading role in funding and molding Satgas Papua (Satuan Tugas Papua, Papua Taskforce) was both widely accepted and widely questioned. That his objective may have been to stir up trouble and discredit Gus Dur, rather than to liberate Papua, seemed clear to many of his (and Theys Eluay's) critics. Suharto and his family have a considerable stake invested in the Freeport mine, which means they benefit from the status quo in Papua, and it is likely that Yorris remains their point man there..$^{36}$ But many Papuans were willing to overlook evidence of collaboration with Suharto; it seemed better to have Eluay, Yorris, and their ilk in the nationalist camp rather than outside and against it in any final showdown with Jakarta, and best to accept quickly an apparent change of heart by erstwhile collaborators pour encourager les autres. ${ }^{37}$

The Papuan mood is an amalgam of fierce resentment and bitterness about the past and chiliastic euphoria about the future, deriving, as I have suggested, from the Koreri-type "cargo" myths which have recurred ever since European contact. The euphoria is what most profoundly separates the people and "intellectuals" (in Papuan terms, that means anyone with tertiary qualifications or a responsible government position). For most of the people, the denial of independence was inconceivable in 1962-63, inconceivable again in 1969, and inconceivable once more in 1984, when an

35 Agence France Presse, June 20, 2000. PT Freeport Indonesia was also rumored to have contributed to the Mubes if not the Kongres. According to Franz-Albert Joku, Freeport was the main source of money for the Papua Presidium by 2001, with Tom Beanal acting as the conduit willing to fund the activity of Eluay as well as other leaders. Interview, Sydney, June 8, 2001.

36 On Eluay and Yorris, see Lindsay Murdoch, "Theys Eluay: Papuan independence leader," Sydney Morning Herald, June 3, 2000.

37 The idea of Papuan "collaboration" with the Indonesian state is, of course, problematic, and the term should probably be reserved for those who have Papuan blood on their hands, Indonesian money in their pockets, or who have acted in ways grossly contrary to Papuan interests. In a sense, the entire Papuan nation and its people have been unwilling collaborators with Indonesia Raya. But so far as leaders are concerned, there is a surprisingly clear line drawn in Papuan opinion between those regarded as tainted by their Indonesian connections, and those who are judged to be "clean." Of the more prominent Presidium leaders, Theys Eluay, Yorris, and Willy Mandowen (on leave since 1998 from Universitas Cenderawasih, where he established connections with the Indonesian military through English language teaching; he is also connected closely to PT Freeport Indonesia) have been widely distrusted or deplored, especially in educated circles, while church leaders Agus Alua (Catholic), Herman Awom (GKI, Gereja Kristen Injili di Irian Jaya: "mainstream" Protestant), and Benny Giay (GKII, Gereja Kemah Kristen Injili Indonesia: mainstream Evangelical) have not been. The NGO activist Thaha Al-Hamid (a Papuan Muslim and reputedly the Presidium's leading strategic thinker), and Don Flassy, drafter of constitutions and theorist of a pre-independence "transitional government," have also kept clean reputations.

Tom Beanal's reputation survived his close connection with Freeport for a time. But now many people consider him to be a "Trojan horse," sent by Freeport to infiltrate and control the independence camp. According to Chris Ballard, Freeport is funding the Papua Presidium Council in order to insure that the future leadership of Papua will be friendly to its mining interests. (Chris Ballard, remarks at a workshop on West Papua: Promoting Reconciliation as a Way Towards Peace Dialogue, held at International House, University of Sydney, and organized by the West Papua Project of the Centre for Peace and Conflict Studies, December 12-13, 2001.)

Questions have also been raised about Franz-Albert Joku, because of his long-standing intimacy with Theys Eluay and other New Order stalwarts in Papua, and because of his Papua New Guinea business activities. 
abortive uprising in Jayapura led to a mass exodus of over ten thousand refugees to Papua New Guinea. And it is inconceivable again today (or at least it was around June 2000) for Papuans whose hopes have been aroused by a notionally reforming government in Jakarta, some new democratic space in Papua, and increased international attention, since the world has begun once again to register Papua's pain and loss: the scores of thousands of dead, disappeared, tortured, imprisoned and exiled people, and the hundreds of thousands of impoverished, disrupted, and traumatized lives.

Under reformasi, the Papuans began to assess not just their losses, but also their strengths, moral and social as well as political and military, in a new light. Although the point of departure in this exercise remains history, they can point not just to their guerrilla forces of long standing, the OPM, but to the new forces that emerged under open political mobilization. In the assessment offered by the organizers at the Mubes in February 2000 nine "pillars" of the new struggle were listed; all these "pillars" were duly represented on the twenty-four member Papua Presidium Council established by the delegates. ${ }^{38}$ It will be convenient to use this list as a peg on which to hang some preliminary comments about the political strengths and human resources of the "civilian" (non-OPM) movement as it emerged under the auspices of Dewan Papua in early 2000.

\section{1) Pilar Agama (Religion)}

West Papuans are overwhelmingly Christian, and the mainstream churches, both Protestant and Catholic, even when they are under "foreign" (Javanese, Dutch, etc.) leadership or influence, are overwhelmingly sympathetic to the national cause. They have offered at least partial sanctuary to those national leaders who also hold formal church roles. The churches-particularly the Catholic church through its Office for Justice and Peace in the Jayapura diocese, and the Protestant GKI (Gereja Kristen Injili)-have actively exposed human rights abuses and sought to hold the ruling authorities accountable for acts of violence. They see it as their mission to protect the people from the brutal and indiscriminate retaliation which so often follows armed or militant action by the OPM fighters (or TNI-orchestrated provocateurs).

But this church posture readily collapses into quietism, and the head of the GKI, Herman Saud (who is not a Presidium member), is rather notorious for calling on Papuans to avoid provoking the government at any cost. Here is a fundamental unresolved dilemma of the Papuan struggle: quietism may save lives in the short run, but only dramatic and often bloody episodes, such as flag raisings, uprisings, attacks on the police or military, and "hostage events," seem capable of propelling West Papua to the status of a live international issue.

\section{2) Pilar Adat (Custom)}

Not only were the two top national leaders ("Theys/Tom") also important traditional chiefs, but the Papua Presidium Council that emerged from the February 2000 Mubes was billed as both "the reincarnation of the New Guinea Council

38 "Duet Tom-Theys Pimpin Perjuangan Papua," Cenderawasih Pos, February 28, 2000. 
established [by the Dutch] in 1961" and "the formal organisation of tribal people in West Papua." 39

Curiously, though, the only one of assembled thousands to choose "tribal wear" at the opening ceremony of the Mubes was Chief Theys himself. During Theys Eluay's own transformation from Golkar trusty to national leader of dissident Papua, he maintained a key political base thanks to his role as head of the LMA, which must now be seen as a more ambiguous institution than Suharto would ever have suspected. This adat leadership at the national level has clear advantages, as it has the potential to mobilize (and be mobilized by) the overwhelming mass of village society, whose local interests have suffered as a result of unrestrained transmigration and the Center's exploitation of Papua's resources. But an accompanying tendency among adat leaders to marginalize intellectuals and neglect the possibilities of developing more modern political structures and approaches is apparent.

Dr. Benny Giay, head of the Walter Post Theological College, Sentani, and others have long argued that a separate-and openly or covertly separatist-political party should be launched for Papua, and indeed Theys Eluay promised to establish one at the time of his 1998 conversion, a promise apparently soon forgotten. There are legal impediments to the proposal, for Indonesian law forbids the establishment of regional parties and requires all parties to be registered in Jakarta, but this law has recently come in for strong criticism at the center. ${ }^{40}$ In any case, clearly the adat basis of current Papuan mobilization has suited the top leaders.

\section{3) Pilar Profesi (Professionals-from the public and private sectors)}

Critics of the new national movement constantly call for more attention to be paid to this group of "intellectuals" - which includes academics-and for the intellectuals themselves to provide more leadership and input. There are respected intellectuals who have figured prominently in the movement, including, most importantly perhaps, Benny Giay, appointed as one of three "moderators" of the Papua Presidium Council in February 2000. There is also Willy Mandowen, professor of linguistics (on leave since 1998) at UNCEN. Mandowen still holds his position as secretary of FORERI (Forum for Reconciliation in Irian Jaya), the key organization behind the negotiations with Jakarta and the planning and document drafting that preceded the successful public-relations coup of the Team of One Hundred.

But other intellectuals are thoroughly alienated from the movement in its present form, including Papua's outstanding human rights advocate, John Rumbiak of ELSHAM (Lembaga Studi dan Advokasi Hak Asasi Manusia, Institute for Human Rights Studies and Advocacy), which is situated close by the UNCEN campus in Abepura.

\footnotetext{
39 Who We Are, Papua Presidium Council website (www.westpapua.net). Franz-Albert Joku claims that at a "historic meeting" in Theys Eluay's Sentani house in June 1999, the decision was taken on his recommendation to assert continuity with the New Guinea Council of 1961and plan for a second Council. Interview, Sydney, June 8, 2001. See also Rowan Callick, "Irian Jaya's new player makes grab for limelight," Australian Financial Review, January 11, 2001. It should be noted that, whereas in February 2000 at the Mubes the newly elected Papua Presidium Council was designated as the successor to the New Guinea Council, in June this honor fell to the Second Papua People's Congress.

40 Interview, Benny Giay, Jayapura, February 22, 2000; "Meeting GAM halfway," Jakarta Post, December $15,1999$.
} 
Rumbiak calls the idea of a Papuan transitional government, which emerged (not for the first time) at Kongres Papua, "ridiculous of course." Like Benny Giay, Rumbiak considers it vital that all participants reflect profoundly on relations among Papuans in order to achieve mutual respect. For him the "issue of primordialism" is unresolved, and he views any rush to independence as fraught with disaster. ${ }^{41}$

Some have suggested that civil servants take on a greater role in the movement, but that proposal is complicated by the taint of collaboration attaching to anyone in straightforward government service. At the same time, the Dewan Papua platform recommends that the proportion of Papuans in senior civil service positions be drastically increased, and indeed by 2001 all bupati (regency heads) save one were ethnic Papuans. There is a good deal of informal coordination and mutual support between the Presidium leadership and established Papuan bureaucratic statesmen with ties to Jakarta, such as Bas Suebu, currently Indonesia's Ambassador to Mexico. These contacts are tolerated by the central government. On the other hand, a top-secret strategy document originating in the military-dominated Ministry of Internal Affairs and dated June 8, 2000 (that is, only days after Kongres Papua concluded) called for Papuan officialdom to be cleansed of pro-independence figures and actually named Don Flassy, then still serving at the provincial development agency, Bappeda (Badan Perencanaan Pembangunan Daerah). ${ }^{42}$ Sure enough, Flassy lost his job in 2001.

\section{4) Pilar Mahasiswa (Students)}

Former students, mostly from Cenderawasih University, were key leaders in the OPM as it mobilized and developed into a province-wide national resistance movement after the Act of Free Choice. Students continue to serve as a conscience of the revolution: hundreds are always ready to confront police or military forces within the university campus. In December 2000, three highland students of UNCEN were murdered and dozens brutally beaten, arrested, and tortured by police in retaliation for an OPM attack on a police post in Abepura which resulted in three deaths (discussed below). Thus the students also have their martyrs, and they feel entitled to criticize national leaders suspected of backsliding. After the May/June Kongres, students urged Theys Eluay to show more willingness to go to jail for the cause! By year's end, he had obliged them, at least briefly, and less than a year later he died in the independence cause.

\footnotetext{
41 Interview, Abepura, February 21, 2000.

In a November 2000 interview, John Rumbiak suggested there ought to be a delay of fifteen to twenty years before independence. "Tomorrow morning if Indonesia collapses and we have independence we will fight each other." Tim Dodd, "The divide tearing Indonesia apart," The Australian, October 28, 2000. Rumbiak also insisted that "a country that is liberated by violence will only sow seeds of cruelty which will be difficult to abolish."

42 An English language summary of this and other top-secret post-Kongres strategy documents (some originating in Jayapura police headquarters) which were leaked to ELS-HAM in November 2000 can be found in TAPOL, Secret operation launched to undermine and destroy the pro-independence movement in Papua, December 10, 2000. Given this document's advocacy of "covert activities" against the independence movement and its recommendation that a "legal umbrella" shield the counter-insurgency forces, the murder of Eluay came as no surprise to many in Jayapura. See ELS-HAM, Preliminary Report: The Abduction and Assassination of Theys Hiyo Eluay was Premeditated and Politically Motivated (Jayapura: ELS-HAM, December 13, 2001).
} 
104 Peter King

Students are also prominent because they help preserve urban links with the OPM leaders in the bush, who are continually seeking trustworthy urban (and foreign exile) spokespersons and intermediaries to represent them. ${ }^{43}$

\section{5) Pilar Perempuan (Women)}

The task of mobilizing women, let alone properly addressing women's concerns, lies very much in the future. Women were very poorly represented at Kongres Papua, and the few women delegates complained that their potential contribution to the struggle was being neglected. Women's potential to serve as peace-makers in a situation that constantly threatens to escalate into violence is also sadly undeveloped in Papua, despite the contributions of such women as Josefa Alomang, an illiterate Amungme grassroots human rights activist who has been a stalwart in the struggle against the Freeport mine for many years, and Papua Presidium Council member and Christian activist, Beatrix Koibur. ${ }^{44}$

"Mother" (or "Mama" or "Sister") Josefa, who was a plaintiff in one of two Amungme cases brought against the Freeport mine, famously once told Jim-Bob Moffett, founder and CEO of Freeport McMoRan, at a press conference outside his home in New Orleans, that she was fed up with Freeport's failure to keep its promises, and that she was going to throw him out of the nokin (in Papua New Guinea, bilum) where she had been nursing him. ${ }^{45}$ (Throughout the New Guinea highlands, babies are carried about in these string bags.) In Aceh, by contrast, women are beginning to emerge in feminist and peace-making, as well as nationalist, roles. ${ }^{46}$ Adat feminism is not so well developed and faces greater obstacles than Islamic feminism-and, of course, the term may be an oxymoron.

\section{6) Pilar Pemuda (Youth)}

Without doubt, the most thoroughly mobilized social formation in Papua today is, or was until early 2001, youth. Thousands of boys, young men, and some girls and

43 A leading Papuan student radical in Jakarta, Demianus Wanimbo, head of the Aliansi Mahasiswa Papua, played a leading role in a major hostage drama of 2001, when two Belgian journalists were kidnapped by the Titus Murip faction of the OPM/TPN (Tentara Papua Nasional, Papuan National Army) active around llaga in the west central highlands. Demianus (falsely) claimed to have "ordered" the kidnapping. In fact, he did have some kind of political mandate from Titus, for he drafted Titus's main statement on the crisis and played a major role in the elaborate arrangements for the hostages' release. This release was orchestrated by two mediators-Brother Theo van den Broek and Dr. Benny Giay - who had been chosen by Titus. Interviews, Benny Giay, Jayapura, August 14, 2001; and Theo van den Broek, Sentani, August 20, 2001. See also "Kidnappers to free Belgians on August 1," Jakarta Post, July 23, 2001. These two men of the church were rather taken aback in their final encounter at Ilaga with hundreds of "OPM Christians" who symbolically "gave back" the Bible to them. "Where have you been all these years?" they were asked.

44 See Annie Feith, "Strategies of Rule, Strategies of Resistance: Women and the West Papuan Nationalist Struggle" (BA Honors thesis, Queensland University of Technology, 2000).

45 On Josefa, see Human Rights Watch, "Indonesia: Human Rights and Pro-Independence Actions in Papua," Section VIII, Note 146.

${ }^{46}$ See Chusnul Mar'iyah, "The Indonesian Political Transition: Democracy and Women's MovementsExperience and Reflections," Inter-Asia Cultural Studies (forthcoming). See also Peter King, "Making Indonesia Work for the People: Chusnul Mar'iyah Thrives on Controversy," Inside Indonesia 64 (OctoberDecember 2000). 
young women flocked to the banner of Satgas Papua beginning in early 1999. Originating as a small group of guards at the house of Theys Eluay in Sentani, and under the leadership of his son, Boy, the Satgas played an important role in safeguarding the top leaders in the period after the return of the Team of One Hundred from Jakarta in February 1999. This was a time when the local security administration tried to crack down on follow-up meetings and other "socialization" activities held at so-called posko ("command posts") all over the province. In the process, the Satgas, with their smart black military-style uniforms, Morning Star insignia, and police-style long batons, spread across the whole province, and came to number perhaps as many as ten thousand by mid-2000.

Satgas was able to provide massive security for the February Mubes and also for the May/June Kongres, although it was already then being criticized as likely to provoke new repression by the security forces, as discussed below. By the end of the year, the security forces were cracking down hard against the organization, and it seemed in some danger of disappearing altogether for most of 2001. If it does finally disappear, the Dewan Papua leadership will have to think carefully about providing alternative outlets for the energy of Papua's youth.

\section{7) Pilar Tapol/Napol (Former political prisoners)}

The two most prominent delegations at the February Mubes-in positions of honor to the left and right of the main podium-were the "Pacific" delegation (mostly longterm exiles living in Papua New Guinea, some of them ex-OPM members) and the socalled Tapol/Napol, survivors of arrest, torture, and long-term imprisonment in Jayapura, Surabaya, Jakarta, and elsewhere. Some were former fighters; some, including their leader, John Mambor, had been arrested in Jayapura for carrying out intelligence activity on behalf of the OPM. ${ }^{47}$ The lives of most of these delegates have been seriously disrupted, and they suffer from special health and psychological problems. By November 2000, Mambor himself was in jail and facing treason charges as a result of his role in the Kongres.

\section{8) Pilar Pelaku serajah ("Playmakers in history")}

This somewhat vague category presumably includes the heroes of the historical struggle, most of them now dead or in exile. It would encompass such men as the leaders of the independence movement before 1962 who went into exile with the Dutch (Nicholas Jouwe and others), and the two great OPM collaborators and rivals of the 1970s (both still living in European exile), Jacob Prai and Seth Rumkorem. ${ }^{48}$ There are also the "civilian" martyrs of the 1980s-Arnold Ap of the Mambesak cultural group and the UNCEN museum, who was arrested and murdered in 1984,49 and Dr. Thomas Wanggai, the civil servant who died, possibly poisoned, in Jakarta's Cipinang Jail in

47 Interview, Jayapura, February 20, 2000. Tapol-tahanan politik, political detainee; Napol-narapidana politik, political prisoner.

${ }^{48}$ For a first-hand report on the factional issue in the bush and in exile, see John Ondawame, "The Land is My Mother: Autobiography of a West Papuan Freedom Fighter" (unpublished).

49 It later became clear that Arnold Ap had been a "minister" in the underground "government" set up by Seth Rumkorem before the latter went into exile in 1982. This government organized the 1984 rising in Jayapura. 
1996 for raising an independence flag of his own devising. Theys Eluay has now joined the ranks of the martyred heroes of the struggle, and the moment may be approaching when the martyrdom of the independence movement's elite and rank and file alike has finally brought Papua to the point where compromise on independence is unacceptable.

\section{9) Pilar Jaringan dialog aspirasi (Political dialogue group)}

The key political dialogue groups before 2000 were FORERI and the group it helped launch into "national dialogue," the Team of One Hundred. But Kongres Papua foreshadowed a much more ambitious dialogue than ever before, for delegates resolved to pursue dialogues and negotiations in order to win de jure recognition of a morally legitimate de facto independence not only from Jakarta, but from the konspirasi powers and the United Nations, as well, in order to undo the betrayals of the 1960s. In any case, the newly minted and theoretically tight-knit Papua Presidium Council leadership was featured as a prime asset of the movement, and although this dialogue group held virtually no dialogue with Jakarta after June 2000, the Presidium's International Moderator, Franz-Albert Joku, had some success in "socializing" the results of the Kongres internationally, as we shall see.

\section{"The OPM is in"*}

It is, of course, striking that the OPM itself is not identified as a pillar in this list. Its absence is testament to conflicting opinions within the movement about the OPM's future role both at home and abroad. The Prai/Ondawame group in exile initially opposed the Theys Mubes/Kongres strategy in favor of a theoretically more representative and less constrained gathering, guided by a less compromised leadership, to be held outside Papua. ${ }^{50}$ But, as Papua Presidium Council member and exiled former leader, Wim Zonggonau, points out, "the OPM is in."51 Since 1998 (and even before), the undefeated OPM had begun to emerge into open politics, and also had been drawn into new divide-and-rule games played by Indonesian military intelligence and the Kopassus special forces, which were intended to disconcert and distract the independence movement as a whole. ${ }^{52}$ The OPM is still militarily capable in its jungle camps, and even outside them, though restrained by the limits of its always primitive armory. It is therefore a prime asset of the movement at home in Papua, while the various groups of OPM exiles abroad continue to play a large, if rather incoherent, role in representing West Papua's grievances to the world. ${ }^{53}$

\footnotetext{
50 Interview, John Ondawame, Sydney, April 19, 2000. See also "West Papua freedom call," Post Courier (PNG), August 3, 2000.

51 Zonggonau, Remarks (see note 2).

52 For background on black "intel" operations, see Richard Tanter, "Intelligence Agencies and Third World Militarization: a Case Study of Indonesia, 1966-89" (PhD dissertation, Monash University, 1991).

53 See Otto [John] Ondawame, "The International Profile and Effectiveness of the OPM," paper delivered at a conference organized by the Centre for Peace and Conflict Studies (West Papua Project) on the topic, "West Papua at the Crossroads: an Uncertain Future," International House, University of Sydney, April 19, 2000.
} 
OPM "General" Bernardus Marwen and a delegation of forty-four OPM fighters lobbying to promote the forthcoming Kongres Papua were received at Jakarta's Merdeka Selatan palace in late May 2000 by none other than Vice President Megawati Sukarnoputri, albeit at a time when President Abdurrahman Wahid (Gus Dur) was planning to open Kongres Papua. (Megawati, a connoisseur of TNI uniforms herself, was seen to examine the military name tag on Bernadus's chest. ${ }^{54}$ At the Kongres, some delegates lobbied successfully to have an OPM group of ten added to the "panel" of 491 delegates with voting rights. 55 And John Ondawame (Prai's deputy at the time of their arrest in Papua New Guinea in 1978), who has long been claiming-for the most part effectively-to represent the OPM abroad, was eventually named as a member of the Papua Presidium Council after the February Mubes. In the fullness of time, Ondawame even managed to doff his OPM hat, at least temporarily, and to speak up on behalf of the Presidium. ${ }^{56}$ The whole issue of the place of the active and the exiled OPM in the new movement obviously needed to be sorted out. ${ }^{57}$ But despite that complication, the Papua Presidium Council leadership asserted that there was unprecedented unity in the newly reconstituted independence movement. According to Clemens Runawery (whose claim was to be sorely tested later in 2000):

Thus, Peter, the election [of the Dewan Papua in February] and recognition of this single national organization (political vehicle for our struggle) under the above format [Presidium of Twenty-Four, Council of Two Hundred, nine pillars, etc.] brings to an end factional fighting, especially factions abroad. A national political organ is now in place endorsed by all representatives from fourteen regions [of Papua] and diaspora delegates [from "Asia" (mainly Indonesia itself), the Pacific and Europe] . . . After almost four decades of disunity . . . we now have a cohesive ... leadership of the Papuan community. ${ }^{58}$

54 "Papua Congress to 'rectify' history," Jakarta Post, May 30, 2000; "Puzzling government," Jakarta Post, June 6, 2000.

55 Mike Atkins, "The Political Situation," Letter to Kabar Irian (www.irja.org), June 14, 2000.

56 Remarks at a press conference on the death of Theys Eluay, Parliament of New South Wales, Sydney, November 15, 2001. Eluay's heir apparent is Ondawame's fellow Amungme (and former teacher), Tom Beanal.

57 According to Willy Mandowen, direct incorporation of the OPM in the Dewan Papua Presidium structure (in which, according to him, the nine mutually reinforcing pillars of the movement ideally constitute a single pillar) would unbalance it. Mandowen insists that the Presidium is pursuing a strategy of strengthening the separate pillars-hence, for instance, the breakthrough national women's conference organized from FORERI offices (which stand opposite the Papua Presidium offices in Kotaraja) and held in Jayapura during July 2001. Interview (with illustrations on table napkins), Pondok Ria Wisata Restaurant, Jayapura, August 16, 2001.

58 Personal letter from Clemens Runawery, PNG delegation to Mubes Papua, March 17, 2000. I am indebted to this letter for its data and commentary on the Mubes and Dewan Papua. Clemens, together with Wim Zonggonau, was designated to carry the Papuan protest against the Act of Free Choice to the UN in 1969. They were both ordered off an airplane and forcibly detained by Australian officials on Manus Island, Territory of New Guinea, and never reached New York.

After the June Congress, the Mubes Council of 200 became a "Panel" of 501, a kind of grassroots parliament of the new independence movement in the regions, while the Presidium, with all nine "pillars" represented, was increased to thirty-one members and functioned quite actively as a national leadership group. Thus it seemed to this observer after the Kongres that, in principle, Dewan Papua had ceased to exist. That, however, has not stopped it being constantly hailed as the fons et origo and guiding spirit of Papua's national revival since 1998, and I have gone along with this "ghost in the machine" theory. In the same 
108 Peter King

On Sunday, June 4,2000, the leadership of the national political organ sounded its basso profundo pipe in the final resolution of the Kongres Papua plenary:

The People of West Papua have been independent as a Sovereign Nation since December 1, 1961 .... Indonesia, the Netherlands, the United States of America, and the United Nations should acknowledge the political rights and sovereignty of the People of West Papua, based on investigation of history, law and social and cultural aspects. ... This resolution again stresses to the peoples and other nations in the world that, based on reinvestigation to resolve history, the People of West Papua have obtained independence since 1st of December 1961. Merdeka! Merdeka! Merdeka!59

Or, in the words of the five-point statement of its political affairs committee, adopted by the Kongres on Saturday, June 3: "West Papua is not a part of Indonesia." 60

December 1, 1961 was the day of a climactic session of the New Guinea Council; the day the Morning Star flag flew for the first time in Hollandia (Sukarnopura/ Jayapura-and now, as many independence advocates would have it, Port Numbay), alongside the Dutch flag; and the day the new anthem, "Hai Tanahku Papua," was sung. The Kongres's final resolution refers to the Political Manifesto of the Papuan National Committee adopted on October 19, 1961 as foreshadowing independence, but there was, strictly speaking, no declaration of independence in 1961, not in October nor December either. ${ }^{61}$ Nor, in a sense, was there one in June 2000 , since the Kongres resolution carefully avoids explicitly declaring independence. However, the media pack reporting on the Kongres immediately interpreted the resolution as just

spirit, I have accepted the common, but illogical, name, Dewan Presidium Papua (Papua Presidium Council), which appears on the Presidium's website.

59 The full text of the resolution is available in the Australia West Papua Association's AWPA Newsletter, No. 5 (May 2000).

60 "West Papua is not a part of Indonesia: people's congress," Agence France Presse, March 6, 2000.

61 The New Guinea Council, with a majority of Papuan members, had been elected in February 1961 and sworn in the following April. The Papuan National Committee of about seventy members was established by the Papuan leaders in the Council. Its October Manifesto clearly asserted a right to sovereignty, as well as proposing the national symbols and anthem which were later accepted by the Dutch. Referring to the UN Charter and UN resolutions on decolonization, the Manifesto then asserted that:

"III. by virtue of the inviolable right we, inhabitants of the western part of Papua, have to our native country;

"IV. in accordance with the ardent desire and the yearning of our people for our own independence, through the National Committee and our parliament, the New Guinea Council, insist with the Government of Netherlands New Guinea and the Netherlands Government that as of November 1, 1961,

"a) our flag be hoisted beside the Netherlands flag; b) our national anthem ("Hai Tanahku Papua") be sung and played in addition to the Netherlands national anthem; c) our country bear the name of Papua Barat (West Papua); and d) our people be called: the Papuan people.

"In view of the foregoing, we, Papuans, demand our own position, equal to that of the free nations and in the ranks of these nations, and we, Papuans, wish to live in peace and to contribute to the maintenance of world peace. Through this manifesto, we summon all inhabitants who love this country and its people to rally round this manifesto and to uphold it, as it is the sole basis for the freedom of the Papuan people."

Text supplied by Evelien van den Broek, Pa Vo, Holland, who comments that on December 1, 1961, the Papuans "officially inaugurated the national symbols of a sovereign state." (e-mail from Evelien van den Broek to Peter King, January 4, 2001.) Independence was expected to come in another ten years or so. See also Osborne, Indonesia's Secret War, pp. 24-5. 
such a declaration-and also accepted, on trust, the intimation that independence had been announced in 1961 - and they were not contradicted by Papua Presidium Council spokespersons, several of whom continued to propagate the myth that independence had already been declared in 1961. So far, the Presidium's noble lie about this "declaration" has not been seriously challenged by anyone.

In any case, the second Kongres Papua does pick up where the New Guinea Council left off when the Dutch capitulated to Indonesian and American pressure in 1961-62. The Kongres empowered the Papua Presidium Council to "establish immediately an independent team" to seek international recognition of Papua's independence via a referendum, and the leader of the Netherlands-based European delegation to the Kongres, Victor Kasiepo, promised to act. ${ }^{62}$ A sixty-page document tabled at the Kongres proposed "Papua" as the name of the proto state, although the Kongres resolution itself seemed more inclined to "West Papua," and boundless confusion persists as to whether "Papua" or "West Papua" is undergoing liberation. ${ }^{63}$ This document also proposed to reconfirm "Hai Tanahku Papua" as the national anthem, the Mambruk bird as the state symbol, and the "Dutch [sic] guilder" as the state currency, while "the official language would be English, the common language Malay-Papuan, [and] the Melanesian language Tok Pidzin" (sic), according to an Agence France Presse summary. ${ }^{64}$ (Tok pisin is the most widely spoken lingua franca of Papua New Guinea.) The Kongres moderator, Thaha Al-Hamid, affirmed that "the Morning Star flag will rise forever in our motherland."65 In addition, Papua Presidium Council member, Clemens Runawery (exile since 1969, living in Papua New Guinea), was quoted by one Australian journalist as saying that the Presidium had plans to

62 Jakarta Post, April 6, 2000. The Dutch, repeatedly accused of first betraying and then neglecting the Papuan cause over the years, have embarked on a historical reconsideration of their own-first of all a commissioned study into "international events surrounding the Act of Free Choice." Letter from Minister of Foreign Affairs to Chairman of the Lower House, June 29, 2000. Text in Kabar Irian, July 8, 2000. And the Papuan independence movement has, for the first time, acquired official international sponsorship. Fellow Melanesian minnow Vanuatu (but not Melanesian superpower, PNG), and the Micronesian microstate, Nauru, have called on the UN to support a referendum on self-determination in Papua. For Radio Australia report and text of speech by the President of Nauru to the Millennium Summit of the UN; see Kabar Irian, September 11, 2000.

${ }^{63}$ At least one Australian journalist and several others reported that Gus Dur had changed the name of the province from Irian Jaya to "West Papua," when in fact Gus Dur chose "Papua" despite the potential for confusion with PNG's southern region, also called Papua.

64 "The constitution of the 'State of Papua' as envisaged in Jayapura," Agence France Presse, January 6, 2000. The document certainly originated with the prolific and proactive constitution drafter and Presidium member, Don Flassy, who was arrested in 1998 for setting up a Papuan Independence Committee which attracted Theys Eluay's endorsement. Flassy proceeded in 1999 and early 2000 to issue a stream of documents in both Indonesian and English under the auspices of this committee and Eluay's tribal council, including proposals about a "transitional" (sometimes "provisional") government for Papua, which implied some form of consent from Indonesia. These documents or their kin circulated at both Mubes and Kongres, but were never formally adopted. Interview, Don Flassy, Jayapura, August 16, 2001. See documents composed by Don Flassy, including "The Papuan Transitional Government," proposed by the Papuan Independent (sic) Committee and supervised by the Papuan Customary Council, Sentani (February 1999), and "Basic Guidelines for the State of Papua," Port Numbay (March 2000). Flassy's proposed currency was a Papuan, not the Dutch, guilder.

65 According to Franz-Albert Joku, only the text of the final resolution of the Kongres is authoritative-no other binding decisions were taken by the Kongres. Interview, Sydney, June 8, 2001. 
establish an electoral commission and boundaries, appoint diplomats, and draft a constitution, but this report appears to have been fanciful. ${ }^{66}$

At the Mubes in February, as we have seen, "Theys/Tom" were appointed as cochairmen of the Papua Presidium Council. At the Kongres, Theys Eluay emerged as sole chairman and was hailed from the podium as "President of Papua," 67 and as "President of the Papuan Government" in one media report. ${ }^{68}$ Tom Beanal graciously accepted, first, "co-" status and then subordinate status as vice chairman to Eluay, but, in fact, his numerical support was almost certainly greater at both gatherings, and Eluay seems to have used tough, New Order-style tactics against him on both occasions. At the Mubes, in the words of one confidential account, "Theys was only elected as [co-] chairman of the Presidium after the Satgas Papua . . . commanded by his son, Boy Eluay, basically took all the Mubes participants hostage in the compound, until they elected Theys ..." Likewise, Tom Beanal's demotion to vice chairman at the Kongres has been described to me as deplorable, "a real coup" on the part of Eluay. The same informant suggested that the "Pimpinin Besar" (Great Chief) was a "real pain," in the view of many, and that Tom Beanal, who stressed preserving the unity of the movement in his own public statements, only went along with this "coup" and the "radical" outcome of the Kongres for the sake of unity. His supporters were reportedly very upset that the "Highland Chief" had been demoted so arbitrarily by the Lowland Chief.69

While Theys Eluay was still alive and "Theys/Tom" were recognized as the two top leaders of the new civilian resistance movement, Tom Beanal was usually portrayed as the more moderate, because he had opposed any direct moves to independence in the past, and some media observers were confidently predicting a "triumph of the moderates" as late as Saturday June 3, 2000.70 But as it happened, not only was Beanal displaced as co-chairman, but the congressional resolutions were thoroughly "radical." One "radical" step not taken, however, was to set up a "transitional government" (pemerintahan transisi). ${ }^{71}$ There is little doubt that the "radical" outcome of the Kongres reflects majority Papuan sentiment. In the words of Clemens Runawery, "The will of two million Papuan people worries us more than Jakarta."72

66 Andrew Kilvert, "West Papuans set up government," Sydney Morning Herald, May 6, 2000.

67 Lindsay Murdoch, "Going West," Sydney Morning Herald, March 6, 2000.

68 Andrew Kilvert, "Machete militias clash as self rule tensions heat up," Sydney Morning Herald, August $6,2000$.

${ }^{69}$ Atkins, "The Political Situation." And not only highlanders were upset. On the eve of the Mubes in February, I found the local delegates in Biak seething with resentment, suspicion, and hostility towards Eluay.

70 Jakarta Post, March 6, 2000.

71 A proposal by Don Flassy supporters to establish a transitional government on July 1, in preparation for declaring independence on December 1, 2000, was discussed but not adopted. Interview, Franz-Albert Joku, Sydney, June 8, 2000.

72 Andrew Kilvert, "West Papuans Set Up Government," Sydney Morning Herald, May 6, 2000. 


\section{"We are at a Crossroads"*}

Of course a declaration does not independence make, and there was much unsettled business to be addressed by the movement after the Kongres, including: the future of Eluay's close collaborator, Yorris, and of the Satgas Papua, which Yorris had been funding; the high risks involved in persisting with the "treasonous" declaration of non-integration, as I shall call it; the difficulties of undertaking serious reflection on intra-Papuan problems; and the issue of how to accommodate (perhaps) as many as one million Indonesians in an independent Papua.

\section{(1) Yorris Raweyai and the Satgas Papua}

There were moves to dismiss Yorris from the Papua Presidium Council at the Kongres, but action was deferred. The issue was to be resolved by the Lembaga Musyawarah Adat Irian Jaya-albeit dominated by Theys Eluay, of course. ${ }^{73}$ As for the Satgas Papua, two serious problems emerged immediately after the Kongres. First, some Satgas members, with Eluay's son, Boy, as head of Satgas, were tending to act as Eluay's personal goon squad, and not only at Kongres Papua. ${ }^{74}$ Secondly, the Satgas Papua threatened to clash with the rival Satgas Merah Putih (Red and White Militia), which was set up by TNI during the early months of 2000 in at least two places, Fak Fak and Jayapura. ${ }^{75}$ (A Sydney press report that these two groups actually clashed in Jayapura at the time of the Kongres was not trustworthy, according to local informants. ${ }^{76}$ )

Since, like its Merah Putih counterpart, Satgas Papua has had the dubious benefit of receiving TNI training as well as Yorris's money, it is quite possible that influential TNI officers, along with forces loyal to ex-President Suharto, were behind both militias-and, of course, it is possible they were supporting Theys Eluay as well. The strongly reformist head of Kostrad, the Army's Strategic Reserve Command, Lt. Gen. Agus Wirahadikusumah, called for Satgas Papua to be disbanded after the Kongres

73 Lindsay Murdoch, "Going West," Sydney Morning Herald, March 6, 2000; "Kongres Perjuangkan," Republika, May 6, 2000.

74 Boy is said to have secured "KKN" (kolusi, korupsi, dan nepotisme) easy money to launch a commercial housing project in Sentani under the New Order, but by 1999 Papuans were moving into the complex without paying, as Indonesians departed from Jayapura under the new pressures of Papuan reformasi.

75 How the pro-government militias emerge is highly reminiscent of East Timor. In Fak Fak a new Satgas Merah Putih "working hand in hand with local police and military," according to Yeremias Tuturop of the Irian DPRD, appeared under the leadership of the Fak Fak regency DPRD deputy chairman during May 2000 in response to an attack on the regent (bupati) by villagers in March. It was composed of both Irianese and Maluku people — the latter perhaps Muslim refugees. Brimob (mobile brigade) police and the new militia then cooperated in looting and destroying houses and religious objects as well as the arrest and torture of forty-five local people at the Fak Fak police station. See "New civilian militia concerns Fak Fak residents," Jakarta Post, May 5, 2000; Lindsay Murdoch and Andrew Kilvert, "Golkar Youth Funding Separatists," Sydney Morning Herald, March 6, 2000. A clone of this Fak Fak militia also appeared in Sorong in anticipation of trouble on "independence day," December 1, 2000. It was still there nearly a year later. Interview, Brother Paulus Titit, Tagaste Convent, Sorong, September 1, 2000.

76 Kilvert, "Machete militias clash as self rule tensions heat up." 
and ordered that its members be arrested for such activities as levying market place taxes. But his order had no immediate effect. ${ }^{77}$

Meanwhile, the precedents set in Timor, which were relevant to the emerging militia problem in Papua, needed to be carefully considered. From early in 2000, Satgas was seen by some observers as a needless provocation to the authorities, which therefore should be disbanded. ${ }^{78}$ In June, the Catholic Office for Justice and Peace in Jayapura reported on the killings in Nabire that had taken place during February-March 2000; these acts of violence followed several confrontations between security forces and local Satgas youth (and other people) defending the Morning Star flag. The report criticized the "fluid" nature of Satgas as apt to invite a military/police response intended to provoke violent confrontation with the people. It argued that Satgas "hangers-on" (often criminal) and "elements ... organized by outsiders" contributed to the tragedy in Nabire. ${ }^{79}$ After Kongres Papua, it seemed obvious to many critics that Satgas Papua needed restructuring, but debates about restructuring soon became academic, as the police progressively dispersed, disbanded, or destroyed the movement following the bloody developments in Wamena during October 2000, discussed below. All over Papua, abandoned and dilapidated Satgas posko were testimony to the crackdown, but Satgas showed an OPM-like capacity to persist nevertheless. ${ }^{80}$ It continued to surface in various hotspots and was strongly in evidence on its original homeground in Sentani for the funeral of Theys Eluay in November 2001.

\section{(2) The Risk of Repression}

One of the Kongres "moderates," in opposing the idea of a transitional government for Papua, declared that "the idea would be tantamount to separatism, and this would justify the Indonesian army and police to wipe us out." 81 Theys Eluay was also alert to this danger. His talent for sophistry and fine calibration of a defiance strategy emerged in a speech he delivered at the Kongres, when he asserted that the Final Declaration "does not mean Papua is separating from Indonesia because legally and

\footnotetext{
77 Kompas, June 7, 2000. Agus was subsequently sacked as Kostrad chief, apparently for exposing corruption by his predecessor, and then seriously considered by Gus Dur as a suitable replacement for Army chief of staff, Tyasno Sudarto, soon to be sacked for involvement in rupiah counterfeiting to finance the militias in East Timor. In the event, a cabal of forty-six generals, including Tyasno, blocked the appointment of Agus. See Jakarta Post, September 20, 2000; Sydney Morning Herald, October 10, 2000; Kompas, October 10, 2000. On such politicking in Jakarta do the prospects for demilitarization, a curb on "black" TNI operations, and a serious assault on "KKN" in Papua depend.

78 Theo van den Broek, conference presentation, "West Papua at the Crossroads: An Uncertain Future," University of Sydney, April 19, 2000.

79 See Catholic Office for Justice and Peace, Nabire: Situational Report (Jayapura: Catholic Office for Justice and Peace, June 2000). In Nabire, the Morning Star flag had flown continually since December 1, 1999 (a national record). Brimob shot and killed three villagers during the incident. On the history and traditions of "youth sat" associated with political parties in Indonesia, see Philip King, "Securing the 1999 Indonesian Election: Satgas Parpol and the State" (BA Honors thesis, University of Wollongong, 1999).

80 Indeed large numbers of Satgas youth contrived to undertake OPM/TPN military training at a remote camp in Bonggo sub-district east of Jayapura from 1999 onwards-2,500 men in total, according to TNI, which attacked the camp in October 2001. TNI failed, however, to capture OPM commander Hans Yoweni. "Military takes Irian Jaya's largest rebel training camp," Jakarta Post, October 28, 2001. Thus the final demise of Satgas might mainly serve to strengthen the OPM.

81 "Papuans reject the creation of provisional government," Jakarta Post, March 6, 2000.
} 
according to our history Papua never became part of Indonesia." ${ }^{2}$ Later in June, as he faced sedition charges, he was reported saying that the Papua Presidium Council continued to recognize the Indonesian government as the legal power in the province. ${ }^{83}$ But in August, Presidium Vice Chairman Tom Beanal declared that the Papuans were committed to the current president of Indonesia, Gus Dur, and that if he were toppled, "the first thing we will do is separate from Indonesia." 84 Separation from Indonesia was evidently a repeatable exercise, since the Kongres had already announced it once in June. However, when Gus Dur was finally deposed in August 2001, no fresh declaration of non-integration was forthcoming.

\section{(3) Adat versus Reflection}

After the Kongres, it was still unclear to what extent the adat/"tribal" element would color or dominate the new movement. The adat support for Chief Theys is not to be doubted. (Rather strikingly, as mentioned above, he alone appeared at the February Mubes flamboyantly arrayed in bird-of-paradise feathers, nokin, and beads.) Each time he was summoned to a court appearance to defend himself against sedition charges for the December 1999 flag-raising in Jayapura, the streets of the capital erupted with a colorful cavalcade of tribal, Satgas, and other supporters. More than twenty large, open trucks crammed full of his supporters careened past me in a few minutes when I happened to be standing watch on February 22, 2000.

But the enthusiasm of pro-adat forces does pose a problem. For whatever reasons, it seems to go against efforts to introduce a more reflective dimension into the movement's deliberations. At the February Mubes, the call by Benny Giay and others for Papuans to reflect on their relations with each other and their future relations with the non-Melanesian inhabitants of the land (who make up 40 percent of the population) was met with peremptory, impatient demands. Enthusiasts demanded that the Kongres get on with the business of declaring independence and moving to confront the Indonesians and set up some kind of Papuan government.

A prominent supporter of Theys Eluay was Franz-Albert Joku. Joku lived in exile from 1966 to 1986, during which time he worked as a journalist and held citizenship in Papua New Guinea. Since his first return to Irian in 1986, he has been active as a Sentani chief himself. At the Mubes Papua, he led a large "Pacific" (mainly PNG) exile delegation, and he spearheaded the attack on the "reflective" position there, declaring himself opposed to "intellectual discussion." When Theys Eluay triumphed at the Kongres, his ally Joku emerged as International Moderator of the Papua Presidium Council and one of the Plenary Leadership of eight who signed the Kongres's final resolution.

At the Mubes, Joku's chief target was the unperturbed and cheerful Benny Giay. Giay declared that the Papuans must reflect on their "big history" (the betrayals of the 1960s, in particular), renew their adat roots, and re-learn their own clan customs, if necessary; in addition, and most importantly, he argued that Papuans must come to

82 Jakarta Post, June 4, 2000.

83 "Papuan Leaders will only dialogue with the President," Kompas, October 6, 2000; "Separatists angered by treason charges against rebel leaders," Indonesian Observer, June 24, 2000.

84 "Papuan independence leaders back President Wahid," Kyodo News, July 16, 2000. 
terms with the otherness of others. ("I am scared of you because I don't know you," he said jokingly.) Benny Giay cited the new, more tolerant atmosphere of reformasi and urged Papuans to avoid the twin pitfalls of tribalism and regionalism. In particular, he said, Papuans should try to transcend the great divide between coastals-especially Biak people-and highlanders. ${ }^{85}$ In this context, he called on tribal leaders to "stay where they are" and not use their positions in such organizations as the Lembaga Adat to try to "come up," since this might provoke inter-tribe conflict and rivalry.

How much current application all of this was supposed to have I do not know. Clearly delegates recognized that it was important for West Papua to avoid the fate of Papua New Guinea. In recent decades, Papua New Guinea has been plagued by troubles: by tribal fighting, which has worsened considerably since Australia's departure; by urban "rascal" gangs, which are a precise reflection of KKN (kolusi, korupsi, dan nepotisme), PNG style; by the criminal greed of the political and business elite; and also by a regional secessionist movement in Bougainville, which in 1989 triggered a disastrous campaign of repression by the PNG Defence Force, supported by Australia, which lasted almost a decade. ${ }^{86}$ Despite the fact that they had this grim example to consider, representatives at the Mubes Papua seem to have made few real efforts to tackle internal conflicts among Papuans. In any case, by November 2000 Benny Giay had decided that his particular concerns were not receiving an adequate hearing and had resigned from the Papua Presidium Council, unhappy with its topdown decision making. ${ }^{87}$

\section{(4) The Indonesians Within}

In February 2000, Benny Giay called for Mubes delegates to consider the drastic demographic changes that have transformed Papua under occupation, and he asked, "What now?" "Are we to be multinational, multiracial or just us-a monosociety?" $\mathrm{He}$ called for solidarity with "good Indonesians": "Our suffering is also the suffering of good-thinking Indonesians." Bring them into the movement, he suggested, mentioning George Aditjondro, the half-Dutch former Tempo journalist and academic who was driven into Australian exile under Suharto and is now the world authority on the Cendana Family billions. ${ }^{88}$

85 This coastal/islander versus highlander divide is also a great source of social and political friction in Papua New Guinea, where the "early contact" and therefore "advanced" Tolai of East New Britain and the Bougainvilleans are in a position roughly equivalent to the Biaks. In PNG highlanders have had to exert themselves to "catch up" with islanders in the Defence Force and Papuan "coastals" in the public service.

86 Under the terms of the Bougainville Peace Agreement signed in August 2001, Bougainville is being given a "one-off" special autonomy deal and the right to a referendum on independence ten to fifteen years after the election of an autonomous provincial government. This interesting solution to a chronic secession problem dating back nearly three decades in total has barely been noticed by Papuans and Indonesians.

87 Benny Giay's views are expounded at length in his book, Menuju Papua Baru: Beberapa Pokok Sekitar Emansipasi Orang Papua (Towards a New Papua: Some Leading Thoughts on the Emancipation of the Papuan People) (Jayapura: Deiyai/ELS-HAM Papua, 2000).

88 George Aditjondro has worked in a community development NGO in Irian, has always defended Papuan self-determination, and has written extensively on West Papua's problems, not least with the former First Family. Aditdjondro contemplates the "constructive breakup" of Indonesia Raya with equanimity. See Peter King, "Autonomy, Federalism or the Unthinkable: Indonesian Debates and Papua's Future," South Pacific Study 21,2 (2001): 49. 
What exactly is the Papuan movement's attitude to the hundreds of thousands of uninvited settlers who have come to Irian from Java, Bali, Sulawesi, Maluku, and, indeed, all over the archipelago? The Kongres leadership issued frequent general reassurances to the Indonesian population, promising that they would be welcome in the new Papua and that they would not be driven out. Dewan Papua even claims that it represents transmigrants. ${ }^{89}$ Tom Beanal, in his closing speech to Kongres Papua, called on the Papuans to respect the rights of non-Papuans-"We need them to develop the country," he said, and "I call on all people in Irian Jaya to continually keep unity so that everyone here can live and go about their business peacefully."

Against these pronouncements, we might pose the view of the Catholic Bishop of Jayapura, Dr. Leo Labar Ladjar (a Flores native himself):

Of course these [Indonesian] people must sincerely work for the benefit of the people of Irian Jaya ... [but] there are many who remain oriented to the regions outside Irian Jaya. It seems they will only stay to amass wealth . . . the impression is not good. ${ }^{91}$

My own street and ojek (motorcycle taxi) sources suggest that Papuan attitudes toward migrants range from "I hate all Indonesians" through "I hate Indonesian men(!)" to real friendliness towards Indonesian people. On the other hand, Papuans recognize, and resent, the fact that many Indonesians have stereotyped Papuans as "primitives," citing as evidence their "native" foods (especially sweet potato), large family size, and agricultural practices. ${ }^{92}$ Nevertheless, Christianity does provide a real basis for solidarity between Papuans and many spontaneous migrants, particularly, perhaps, Minahasans from North Sulawesi and Bataks from North Sumatra. There are also Javanese Christians residing in Papua who are thoroughly sympathetic to the Papuan cause and not only as a result of intermarriage. ${ }^{93}$

\section{"We are in the towns now"*}

Two opposing, politico-demographic pressures are in play in Papua, and it is not clear which one will prevail in the long run:

In-migration: Despite the political turmoil of the year 2000 in Papua, new migrants have continued to arrive in the region, for internal, inter-province migration is still the right of all Indonesians. The influx has comprised not only refugees from Maluku and elsewhere (even Timor) in the crisis-ridden archipelago, but also (still) some spontaneous immigrants from Sulawesi. Jakarta even announced plans to send new

${ }^{89}$ Who We Are, Papua Presidium Council website (www.westpapua.net). (This website is out of date, however.)

90 Neles Tebay, "West Papuans declare independence from Indonesia," Jakarta Post, May 6, 2000.

91 Interview, Jakarta Post, June 20, 1999.

92 See Budiardjo and Long, West Papua: the Obliteration of a People, p. 59, for examples of amazingly crude "before and after" (Indonesianization) government posters addressed to village people. On the issue of antiJavanese sentiment, as such, see the report of a presentation by Lance Castles of Gadjah Mada University at a seminar in Jakarta on July 6, 1999: "Do the Javanese have a stranglehold on power?" Jakarta Post, June 13, 1999, and "Resentment triggering unrest in Irian: Expert," Jakarta Post, August 4, 1996.

93 Interview, Brother Budi, Office for Justice and Peace, Catholic Diocese of Jayapura, February 23, 2000. 
transmigrants early in 2000. But by the end of that year, with provincial governments in Papua and elsewhere demanding that new transmigration cease and the often miserable and neglected existing settlements be consolidated, the central government finally bowed to the inevitable and declared an end to the New Order scheme for redistributing population between islands. ${ }^{94}$

Out-migration: At the same time, since 1998 there has been great and growing pressure brought to bear against Indonesians everywhere in Papua - in the highlands and in and around Jayapura especially, but also probably in most regencies-both by the OPM and by the people at large..$^{95}$ So there may have been a net outflow of Indonesians from Papua since 1998, although many Papuans would vehemently deny it. ${ }^{96}$ In any case, a psychological shift has taken place. In the words of Wim Zonggonau, speaking of Melanesian Papuans: "We are in the towns now."97 And indeed, Jayapura/Port Numbay no longer seems to be quite so emphatically the Asian town sprung up in the heart of Melanesia that so many observers noted just a few years ago, even though, to my eye, the Indonesian Asians of Jayapura still look very comfortable doing what they do, and they are widely reputed to regard Irian/Papua as "Paradise," notwithstanding its reputation as a primitive hardship post. But even if one accepts that the tide has turned for the threatened Papuan majority, big questions remain. On the assumption that about 800,000 non-Papuan Indonesians, in a total population of 2.1 million, ${ }^{98}$ will be around for some time to come, there are two large issues for militant Papua to resolve.

First, if West Papua does manage to establish the electoral commission described in a document circulated at the Kongres, how will that commission deal with regulating the franchise in an independent Papua? Will there be "blood" requirements for citizenship-cultural, linguistic, residential, and so forth?-and if so, for how long? Should such a commission require political tests, loyalty oaths, repudiation of any other nationality? Latvia and Estonia, two Baltic states with large Russian-speaking

94 "The government has ceased regular transmigration," Kompas, December 6, 2000. The minister explained that "regular" (inter-province) transmigration had ceased (in August) under Law No. 22 of 1999 on regional autonomy in order to minimize so-called "horizontal conflict" (between settlers and indigenous peoples), but "local" (intra-province) transmigration would continue.

95 In an attack on the Arso transmigration settlement near the northern border with PNG on May 5, 1999, an OPM group led by Hans Bomay killed three settlers and took eleven hostages into PNG's Sandaun province. The hostages were later freed by PNG security forces. Jakarta Post, December 5, 1999, and June 21, 1999. Bomay himself was eventually killed by followers of another OPM commander, Mathias Wenda. Jakarta Post, May 28, 2000. Reports at the time of the hostage taking make it clear that Bomay's group, like elements of Satgas Papua, had been receiving aid and training from Kopassus special forces. For a summary see Human Rights Watch, "Indonesia: Human Rights and Pro-Independence Actions," Section V, Note 58. Even if Kopassus was behind the Arso killing, this does not alter the fact that Papuan resentment has been a significant force pressuring transmigrants to leave the province. See also Neles Tebay, "Why Papuans want to secede from Indonesia," Jakarta Post, February 12, 1999

96 "Every PELNI [state shipping line] boat-and there are three a week-has three thousand new people on it, and we don't know how many are leaving." Interview, Don Flassy, Jayapura, August 16, 2001. The census does not inquire into ethnicity or even birthplace.

97 Zonggonau, Remarks (see note 2).

98 Official 2000 census figure. For a careful survey of available data on the "ethno-demography" of Papua, see Jim Elmslie, Under the Gun: Indonesian Economic Development versus West Papuan Nationalism (Adelaide: Crawford House Publishing, 2002), Chapter 5. 
minorities dating from the period of Soviet occupation, have been in constant trouble with the Council of Europe (not to mention the Russian government) because of their restrictive citizenship and franchise laws, but the populations of these two countries feel that these laws protect their national existence, which was violated by aggressive in-migration during the period of foreign occupation. Most Papuans feel the same way. In fact, the Papua Kongres's Committee for the Independence of West Papua reportedly produced a draft constitution which provides for "a federal republic ... of six territories" and "stipulates that citizenship will be automatic for all people of Papuan or Melanesian origin, with laws to determine the rights of those of other ethnic origins." 99 Of course, restricting citizenship could destroy any possibility of mobilizing a significant number of Indonesian settlers behind Papuan independence, and that could be a very big mistake, since a small, but strategic, group of first-generation Indonesian settlers has proved ready to support Dewan Papua.

Agus Sumule, a leading academic, is a good case in point. He holds a doctorate from the University of Queensland and teaches agricultural economics at the newly independent Universitas Papua, Manokwari. He joined the Manokwari contingent to the Papuan People's Congress, where he was "elected" (without nomination) as one of its twenty representatives on the Kongres Panel. But Sumule's family hails from the island of Sangir in North Sulawesi, and he was born in Makassar before his parents moved to Irian as teachers in the 1960s. His straight hair and businesslike manner and methods set him apart from most of his fellows at the Kongres. Nevertheless, he is a Christian and does regard himself as a native-he has a fair conversational command of $\mathrm{Me}$, the language of the Paniai people. Most importantly, he is clearly accepted by fuzzy-haired Papuans themselves as some kind of blood brother. His views on IndoPapuan identity are intriguing. "We are Papuanised to the extent of supporting the idea of independence," he says. He estimates that opinions about merdeka among Indonesian settlers are distributed as follows:

5-10 percent are "really hostile" to independence

35 percent are "at least not hostile"

The rest are a "floating mass" (massa nugamba), he contends, using old New

Order jargon-they are able to be convinced of the need for independence. ${ }^{100}$

Obviously, if the case of Agus represents some kind of wave of the future-and it may ${ }^{101}$ - the independence movement needs to connect more systematically with its potential Indo-Papuan constituency.

The second large issue that must be resolved by the Papua majority concerns a referendum. What part should a referendum play in Aspirasi Merdeka strategy, given developments in East Timor and Aceh? The Kongres's final resolution proposes that a referendum on independence under UN auspices be held in Papua, but this proposal is

\footnotetext{
99 "The constitution of the 'State of Papua' as envisaged in Jayapura," Agence France Presse, June 1, 2000. Don Flassy's supporters were presumably behind this proposal.

100 Interview, Agus Sumule, Abepura, August 15, 2001. On Agus, see also Note 25 above.

101 When asked whether she was Papuan or Indonesian, Ina, a law student at UNCEN, who was born in Jayapura of Flores parents, responded, "Papuan, of course." Interview, August 24, 2001. Ina regards independence as a long-term option requiring development of human resources in the meantime, as do some of the more thoughtful and embattled Papuan intellectuals.
} 
not being widely or strongly espoused, for obvious reasons. However, a referendum might be the most effective strategy to lay to rest the Indonesian government's persistent accusation that the Papua Kongres and its organs do not represent Papuan opinion in its widest sense. In June 2000, Gus Dur claimed, in the words of the hardliners at Antara (the national news agency), "to know exactly that the majority of Papuans actually prefer to remain part of the Indonesian nation." According to the President, unrest in Papua is caused by a cultural gap between educated and uneducated: "Those who know nothing think that it is easy to demand independence by pressing other people." 102 Note, this analysis is not completely at variance with the analysis offered above by Benny Giay and others who advocate a rekonsiliasi strategy.

At the least, we can conclude that rekonsiliasi must be "à tous azimuths," as the French say-it must involve Papuan reconciliation with the Indonesians "within" as well as "without," and reconciliation among Papuans generally, including those longexiled. In this perspective, there could be a long, difficult, but relatively peaceful transition to independence, rather than a short traumatic one, as was the case with East Timor. Wim Zonggonau speaks of a ten-year haul-independence by $2010 .{ }^{103}$ And that raises perhaps the most important strategic question which faced the independence movement after June 2000. Should the civilian leadership push on and try to make their declaration of independence stick by defying Jakarta, or should they try first to negotiate an acceptable special autonomy status, which could serve as a bridge to independence?

\section{Kongres Aftermath}

This seemed to be the most important issue confronting the Dewan Papua leadership in June and July 2000, but thereafter their entente with Gus Dur began to come apart, and by October it was in tatters. At a special MPR session convened in August, the president found himself weakened by scandals and political obstruction, as well as by his own lack of achievements, and forced to cede power at least notionally to his vice president, Megawati Sukarnoputri (daughter of the architect of Papua's forced incorporation into the republic). In such an atmosphere, Gus Dur's attempts at reconciliation with the Papuans were condemned as appeasement. His indulgent flag-flying policy (Morning Star flags could be flown so long as there weren't too many of them, and none was larger or elevated higher than the Merah Putih) and the changing of the province's name were widely condemned. At the same time, August 2000 , the unelected military presence in the MPR was being extended from the year 2004 to 2009, and these same praetorians were lobbying furiously and successfully for a constitutional amendment that would block future prosecution of past military human rights crimes under retrospective laws-in Papua, as elsewhere throughout Indonesia. ${ }^{104}$ To make matters worse, the signs of a police and military buildup in

102 "President asks transmigrants not to leave Papua," Antara, June 6, 2000.

103 Wim Zonggonau, presentation at conference organized by the Centre for Peace and Conflict Studies (West Papua Project) on the topic, "West Papua at the Crossroads: An Uncertain Future," University of Sydney, April 19, 2000.

104 "MPR approves nine decrees," Jakarta Post, August 17, 2000; "Past rights crimes could get protection," Jakarta Post, August 19, 2000. 
Papua were soon unmistakable; within a couple of weeks, more than three thousand new Brimob mobile police and "non-organic" (Kostrad) troops had been deployed in the province. 105

After a preliminary skirmish in which three flag raisers were killed by Brimob in coastal Sorong during July, a bloody showdown of sorts erupted in highlands Wamena in October. There locals reacted violently against a police attempt to carry out orders from Jakarta (apparently originating with the vice president) to pull down the Morning Star flags flying all over the Baliem Valley. Two defenders of the flag were shot dead. Seasoned Dani tribesmen and Satgas Papua youth alike retaliated against the local Indonesian transmigrant and business community with unprecedented ferocity. The provisional death toll was eleven Papuans and nineteen settlers. ${ }^{106}$ These deaths marked a watershed in Papuan-settler relations, as the Dani signaled clearly that the settlers were now hostage to the repressive policies of the government, and the settlers and civil servants in their turn signaled that Wamena meant finis for them. They began to depart in the hundreds, if not thousands, from all over Jayawijaya regency, abandoning schools, medical posts, and government offices. (Ominously many "coastal" Papuans were among the evacuees from Wamena; some of these also swore never to return.) $)^{107}$ The demographic balance in the province, at least the highlands, seemed to be tipping decisively against Indonesia Raya, and in the weeks that followed threats against immigrants of all kinds were issued by the OPM.

Wamena was also a watershed for the PPC, caught between highlanders, on the one hand, who condemned it for agreeing to obey government restrictions on flag flying (as it did on November $10^{108}$ ), and police on the other hand, who accused it of flouting those restrictions. ${ }^{109}$ In any case, before the anniversary of December 1, Theys Eluay

105 Peter King, "Why foreign pressure is needed now in Papua," Sydney Morning Herald, September 4, 2000.

106 Lindsay Murdoch, "30 die in riots over independence flag," Sydney Morning Herald, October 9, 2000; "Govt bans separatist flag in Irian Jaya," Jakarta Post, October 13, 2000.

107 "Traumatized settlers leave Wamena in the Stone Age," Indonesian Observer, November 20, 2000. When I toured the Baliem in August 2001, the teacher shortage was still acute, illustrating a deep but obvious truth about the situation in Irian: it is utopian to expect "development" strategies and provision of money for delivery of services to solve Papua's problems in the absence of fundamental reforms. Interview, Paul Wetipo, Head, EduVenture English Language School, Pyramid, August 22, 2001.

Paul recounted an apparently rather typical Papuan encounter with a Javanese professor at UNCEN. "I am under Indonesia," he said to his linguistics teacher. "Until now I can do nothing-so how has Indonesia trained me so that I can stand alone? You are stopping me: you don't give me opportunity."

"Yes," replied the teacher, "you will make mistakes."

"But I have to learn from my mistakes..."

108 Rowan Callick, "Indonesia allows Morning Star flag to fly over parts of Papua," Australian Financial Review, February 11, 2000.

109 Until this point, the PPC was beginning to take on the aura of the "provisional" or "transitional" government whose establishment had been debated earlier in the year. In November, T. N. Kawai, chairman of the DPRD, told detikworld: "We feel left behind by the Papua Presidium." (In fact, he, like many others, had jumped on the Presidium bandwagon earlier.) See detikworld, November 2, 2000. A lengthy article by an American reporter found "civil-service infrastructures ... withering" in Papua and spoke of a "government-in-waiting" (the PPC) able to mobilize an "adat legal structure." This same report noted Satgas Papua's success in (illegal) taxation activities. See Jay Solomon, "Indonesian islands tout separatism," Wall Street Journal, November 29, 2000. 
and four other PPC leaders were thrown in jail, charged with various kinds of sedition. ${ }^{110}$ Papua Presidium Council Vice Chairman, Tom Beanal, still walking free, was defiant-if the police arrested him, he declared, the people of Timika would close the Freeport mine. ${ }^{111}$ However, he had little choice but to conduct a subdued and "thin" anniversary ceremony in Jayapura on December 1, at which he was unable to report any progress in implementing the declarations of the June Kongres, and unable to offer an unequivocal reaffirmation of "non-integration" - let alone independence-in the presence of saturation police and military security.

The independence movement, as a whole, was now in disarray. On one hand, the Theys Eluay camp saw, or professed to see, the failure to arrest Tom Beanal as evidence of his complicity with the government and PT Freeport Indonesia. ${ }^{112}$ On the other hand, the highlands/OPM cadre perceived Eluay's incarceration as a scam. They believed Eluay had been jailed to protect him from the wrath of the people, who had been outraged by the Papua Presidium Council's compromised response to flag-flying restrictions and the feeble December 1 ceremony, not to mention the Council's new agreement with the police to vacate Satgas Papua headquarters at the Irian Jaya Arts Centre (the former New Guinea Council building where the Morning Star was raised in 1961) and further restrict displays of the independence flag to five locations in the whole province. ${ }^{113}$ With the Papua Presidium Council's top leadership mostly in jail, accused of "selling out" on all sides, and also badly split, it was the turn of OPM leaders to withdraw their support for the Presidium leadership and begin to reclaim their own primary role as leaders of the political struggle. ${ }^{114}$ For his part, Tom Beanal was suggesting a two-pronged approach for the future: guerrilla tactics through the OPM, and a dialogue with Jakarta through the rump Papua Presidium Council, if possible. ${ }^{115}$

110 The other members of the Presidium arrested were its secretary general, Thaha Al-Hamid, its moderator, Reverend Herman Awom of the GKI, Don Flassy of the provincial development board, and Tapol/Napol leader John Mambor.

111 "Papuan leader, Tom Beanal," Tempo Interaktif, November 29, 2000.

112 Agence France Presse, December 4, 2000. In a letter smuggled from jail, Theys Eluay asked, "Is there any hidden deal between the police chief and fellow Presidium members who have not been detained or does it have something to do with funds provided by Freeport?" Lindsay Murdoch, "Police holding separatists in defiance of Wahid," Sydney Morning Herald, December 9, 2000. (Gus Dur by this time had lost all control of events in Irian to his own Cabinet, TNI and the police.)

113 "Police enter headquarters of pro-independence guard in Irian Jaya," Agence France Presse, February 2, 2001. A contradictory and rather surprising version of Eluay's position is that he had hopes of being liberated from jail by his followers and thought there was a real prospect of independence. Telephone interview, Benny Giay, February 28, 2001. Perhaps Eluay was showing "Koreri susceptibility" himself here.

114 "Political drama protects Theys," koridor.com, December 5, 2000; "Brutality replaces dialogue in separatist Indonesian province," Agence France Presse, December 12, 2000. The OPM/TPN had agreed to recognize the authority of the PPC at a meeting in Vanuatu during July 2000. Aboeprijadi Santoso, "Gus Dur ends his honeymoon with Papua," Jakarta Post, December 21, 2000. The mandate was withdrawn by Mathias Wenda on behalf of the OPM early in December 2000. Jakarta Post, December 7, 2000. According to Kelly Kwalik in January 2001, "The [Papua] Council is a fabrication of Indonesian supporters." Tempo Magazine, January 16-22, 2001.

115 "Police seize Papuan militia HQ" Jakarta Post, December 4, 2000. 
Meanwhile, following a violent incident in Merauke (six people were fatally shot during another provocative flag-lowering exercise on December ${ }^{116}$ ), another bloody conflict erupted in Jayapura on December 7. Dani tribesmen, apparently seeking revenge, raided a police post in Abepura near the university campus, and two Brimob policemen and a civilian were killed. (Some people contend this attack was engineered by Kopassus and was therefore not "tribal," except in the sense that it might reflect police-army rivalry. ${ }^{117}$ ) This attack, in turn, triggered a minor holocaust at UNCEN, where dormitories of central highlands students were raided by police in retaliation for an attack these students had actually refused to join. Sixty students were arrested amidst general mayhem, another was shot dead, and two of the detained students were tortured and beaten to death in the presence of a Swiss journalist, Oswald Iten, who had been arrested for photographing the final (forcible) eviction of Satgas Papua from the Arts Center.

The police explained to Oswald Iten that their work with clubs, staffs, split bamboo whips, and boots was "normal" retribution for the death of policemen, and that the casualty imbalance at Wamena in October had been "a disgrace for the police." 118 At Wamena, the police had called on the immigrant Indonesians to close ranks, arm themselves, and create a self-defense system (siskamling). ${ }^{119}$ In the purge that followed, not only Satgas Papua youth, but several local members of the Papua Panel (former delegates to the May/June Kongres Papua), who had tried to restrain the Dani attack against flag desecrators and settlers, were arrested and charged with treason. Back in Jayapura, the city police chief thoughtfully remarked that if attacks on settlers continued, "I won't be able to stop the Laskar Jihad flooding in."120 The unspoken assumption was that militant Laskar Jihad members from the two Maluku

116 Agence France Presse, December 2, 2000.

117 If Kopassus was behind the Abepura attack, it may have seen benefit in simultaneously provoking and punishing the police. We might note here that in July, Kostrad soldiers and police staged a shootout in Timika where there is enduring tension between them (allegedly over the spoils of the local black economy-drugs, prostitution, illegal logging, trade in protected wildlife, etc.). See Solomon, "Indonesian islands tout separatism." On TNI/Freeport synergies, see Denise J. Leith, The Politics of Power: Freeport in Suharto's Indonesia (Honolulu: University of Hawaii Press, 2002), chapter 9.

Armed clashes between police and TNI under reformasi-in Maluku and Central Kalimantan as well as Papua-seem to be a part of the price being paid for the government attempt to place the police outside the military chain of command and give them a primary role in keeping domestic peace during serious disorder.

118 Oswald Iten, "Prison, torture and murder in Jayapura," Neue Zurcher Zeitung, December 22, 2000 (Kabar-Irian, December 31, 2000; Sydney Morning Herald, September 1, 2000). During Iten's discussion with the Jayapura police chief, it became clear that it had never occurred to the chief that there was potential scandal in a protected foreigner witnessing murderous jail brutality, however routine, first hand. Thus the psychology of official impunity in Irian. For a thorough report by Kontras-Papua and other NGOs on events in Wamena and Abepura between October and December 2000, see "Wamena Tragedy a Provocation," TAPOL Bulletin Online, 161 (March/April 2001). The definitive report on Abepura is "Violence and Political Impasse in Papua," Human Rights Watch 13,2 (July 2001).

119 ELS-HAM Statement, 10/21/00 (Kabar-Irian, October 23, 2000). See also "Violence and Political Impasse in Papua," Chapter 4.

120 Agence France Presse, December 1, 2001. Laskar Jihad is the Java-based armed Islamic militia which Gus Dur, despite clear instructions to his security forces, had been unable to stop from flooding into Maluku earlier in 2000. See also Noorhaidi Hasan's article on the Laskar Jihad in this issue of Indonesia. 
provinces would construe fresh Papuan attacks on Indonesian settlers as a Christian threat to Islam, and would respond accordingly.

But, of course, an equally possible scenario in Papua could be the one which was shortly to erupt in Central Kalimantan, where large-scale transmigration from the grossly overpopulated island of Madura (a part of East Java province) over the entire New Order period had marginalized, demoralized, and displaced most of the indigenous Dayak population. When the Dayaks finally turned against the "accessible responsible" elites in their own region (the government in Jakarta being out of reach), it turned out that the Jakarta government and its agents on the ground didn't really care. Police and TNI soldiers stood aside as hundreds of Madurese were slaughtered (some by quasi-ritual beheading) and tens of thousands were driven from the province, apparently forever. The national media tended to describe the situation as "two unpopular groups fighting each other." The message for Papuans who might be tempted to attack "their" settlers (and resist "outsider" domination of small-scale urban trade and business) by direct methods was ambiguous. In the end, TNI and the police might also stand aside in Papua-or they might not. ${ }^{121}$

The main OPM leadership operates in the northern border area opposite (and also in and from) Papua New Guinea. This leadership claimed responsibility for the Dani attack on Abepura, which they said was meant as retaliation for the new December 1 restrictions on flag displays and also meant to show that "the OPM, especially the TPN [Tentara Papua Nasional] soldiers, are moving" - not paralyzed, like the Papua Presidium. OPM military commander Mathias Wenda was identified as the mastermind of the Abepura attack. ${ }^{122}$ Within weeks, Wenda had been arrested inside Papua New Guinea for illegal entry after operating freely there for years. Wenda and his deputy, James Kogoya, were also charged with raising an illegal army, and they faced not only a PNG court, but also a threat of extradition to Jayapura. ${ }^{123}$ The leading OPM spokesperson in Australia, John Ondawame, announced that Bernard Marwen, veteran commander in the southern sector of the border region (who had been received by Megawati in Jakarta in May 2000, as recounted above), would be assuming Wenda's role and responsibilities. ${ }^{124}$ But in fact, the charge against Wenda and Kogoya

121 The Dayaks in Sampit and elsewhere were careful to avoid attacks on Javanese of any kind.

122 "Separatists behind market attack in Irian Jaya: rebel commander," Agence France Presse, December 11, 2001. AFP's interview with Hans Yoweni at Demta, west of Jayapura, identified him as OPM's supreme commander and minister of defence, Wenda as armed forces commander, and Kelly Kwalik (architect of the 1977 Freeport pipeline sabotage and the 1996 Mapenduma hostage crisis) as chief of the general staff. Expert OPM and TNI/Kopassus watchers in Jayapura were not convinced by Wenda's claim of responsibility for the Abepura attack. "He would claim it, wouldn't he?" was one comment. Many believe that the attack was staged by Kopassus provocateurs, for they doubt that a large group of highlanders could penetrate TNI positions, which were on top alert the night of the attack. Other possible purposes of provocation would be to demonstrate the need for a continuing TNI presence in Papua, which has so many lucrative pickings for the soldiery (including copper mining revenues used to build military infrastructure and the copper mine infrastructure used by the military) and to derail initiatives for peaceful dialogue with the Papuans.

123 Agence France Presse, January 25, 2001.

124 Ben Bohane, "Guerrillas regroup after leader's arrest," Sydney Morning Herald, January 31, 2001. 
was dismissed in May 2001 on the ground that they were not PNG citizens, and both were freed. 125

The OPM itself was clearly in disarray. As for the Papua Presidium Council, while its surviving leadership in Jayapura seemed to be dormant or inoperative, on the international scene several top leaders, including Tom Beanal, had attended the October 2000 summit of the Pacific Islands Forum as part of Nauru's delegation. Building on this success, its international affairs moderator, Franz-Albert Joku, mounted an effective campaign to protest the arrest of the top leaders and called for the deployment of UN peace monitors in Irian. He also confronted Australia's foreign minister, Alexander Downer, over Australia's post-Timor diplomacy, which supported the territorial status quo in Indonesia. Downer had expressed the opinion that the movement for Papuan secession was likely to trigger new violence on a large scale throughout the archipelago, but Joku would not allow that Papuans "should be condemned to eternal slavery" by the Australian government. ${ }^{126}$ This statement resonated among citizens in Australia, precisely because of the disastrous consequences which flowed from the Australian government's prolonged support of Indonesia over East Timor. ${ }^{127}$

At the beginning of the new millennium, not only was the Satgas Papua under ban, but so, more or less effectively, was the Morning Star flag, which had largely disappeared in Jayapura. ${ }^{128}$ Although Gus Dur continued, at least rhetorically, to address the jailed Papuan leaders as his "brothers" and negotiating partners, the government's grand strategy for reconciliation with Papua now seemed to be a familiar mixture of New-Order-style repression and imposed "special autonomy." Gus Dur was embattled, fighting for his political life against 90 percent of the parliament and many of his own cabinet ministers, as well as against the police and military, who had been flouting his peace strategy for many months by intensifying their own activities in

125 Post Courier, May 25, 2001. According to journalist Mark Worth, who spoke to Wenda in Wewak jail, the PNG government is chiefly interested in mollifying Jakarta rather than seriously impeding OPM activity within PNG. Interview, Sydney, May 5, 2001.

126 "West Papuan independence leaders criticize Australian government," Radio Australia, December 14, 2000.

127 Peter King, "Why foreign pressure is needed now in Papua." Australian Prime Minister John Howard announced an end to the Australian policy of "over-accommodation" in upholding the integrity of Indonesia by brutal methods at the time of the Australian-led InterFET operation which finally, as it were, confirmed the referendum result that set East Timor on the road to independence in September 1999. See Rodney Tiffen, Diplomatic Deceits: Government, Media and East Timor (Sydney: University of New South Wales Press, 2001), Chapter 6. But a policy of renewed over-accommodation in all but name was apparent well before the time of Kongres Papua in June 2000.

128 According to Benny Giay, however, it was still flying in Enaratoli, Paniai regency, and being defended by Satgas Papua, in late February 2001. Telephone interview, February 28, 2001. Police and military commanders in Jayapura had been announcing a total ban on the flag since soon after the August 2000 MPR session; but the Papua Presidium Council has continued to stand by its October 2000 agreement with provincial authorities which permitted flags to be flown at tribal centers in five regencies. Unconfirmed reports suggested that Satgas Papua was headed underground, with possibly thousands of youth receiving military training in bush locations, in which case the Satgas would become a kind of alternative or quasiOPM, and the PPC could no longer claim to be a civilian and non-violent political force. In August 2001 only one flag-at Theys Eluay's house in Sentani-was "officially" flying in Papua. Presumably, however, many were still flying under OPM auspices in the bush. 
Papua and Aceh. That repression in Papua had been tried and failed for thirty-eight years, and that the New Order dictatorship had been built and had thrived on "organic" violence and military impunity for thirty-four of those years, was once again a minor consideration. That all Indonesians were again being expected to pay a heavy price for upholding the integrity of the republic by violent means was, for the moment, no longer a consideration at all.

\section{The Future of West Papuan Nationalism}

Franz-Albert Joku identifies three phases of Papuan nationalism in the post-Dutch era, when most Papuans, in one way or another, have sought to resist the Indonesian occupation and its threat to extinguish Papuan identity. In the first phase, which coincides with the last period of Dutch rule, the leaders of the New Guinea Council (Marcus Kasiepo and Nicholas Jouwe, in particular) conceived and promoted the wellknown national symbols that have endured up to the present, and asserted a right to self-determination and ultimate independence in the face of collapsing Dutch resolve to continue the decolonization process and guarantee this right. These key Papuan leaders went into exile with the Dutch in 1962.

The second phase saw widespread uprisings against the Indonesian occupation, the formation of the OPM (in 1965), and the inception of a long history of Papuan resistance to Indonesian rule. There was a notable upsurge of resistance against the Act of Free Choice in 1969; a declaration of independence in the name of a temporarily united OPM under Seth Rumkorem in 1971 ${ }^{129}$; widespread rebellion and repression across the central highlands in 1977-78, associated with Suharto's corrupt national election in that year; and a large-scale refugee exodus to Papua New Guinea in 1984 (conceived and partially organized by Rumkorem, who was in Greek exile at the time). By the mid-1980s, members of the other main OPM faction under Jacob Prai and John Ondawame had been in exile for six years, and no comparably influential leaders emerged before reformasi in 1998.

In the third, post-reformasi phase, according to Joku, national leadership passes definitively to the Papua Presidium Council, which has discovered the correct "civilian" formula for struggle, where new democratic space permits open political interaction among Papuans and between Papuans and Indonesians. As a result of such strategies, the Papuan resistance can make a more effective appeal to international opinion. According to Joku, the OPM should now fully recognize the Dewan Papua and the new-style national struggle and support them both, acknowledging the strengths inherent in the consultative approach and demonstrated by the successful grassroots mobilization efforts of the Theys Eluay-Tom Beanal leadership and this leadership's ability to engage at least one Indonesian president in dialogue. ${ }^{130}$ From Joku's perspective, the torch of freedom has been handed from one generation to the next, exclusively legitimizing the Papua Presidium Council leadership and its strategies since the fall of Suharto.

129 The date of Rumkorem's independence "Proclamation" day, July 1, 1971, has more resonance in OPM circles than December 1, 1961. See Osborne, Indonesia's Secret War, pp. 56-8. 
However, most OPM leaders, whether at home or in exile, have been willing to support the Presidium only partially and conditionally for the several reasons explored above. Specifically contesting Franz-Albert Joku's historiography, John Ondawame maintains that there is and has been only one legitimizing thread in the national struggle: the movement of active Papuan resistance fighters who have waged the struggle and sustained the symbols for nearly forty years; who have not temporized or compromised; and who are not (although this is contestable) tainted by collaboration with the post-1962 occupier. This movement is, of course, the OPM, from which any new "civilian" political movement must seek or be granted its legitimacy. ${ }^{131}$

Given the protracted and increasingly bloody crackdown in Papua since mid-2000, Joku's argument seems somewhat academic. It is possible that the leaders of Dewan Papua will find themselves serving long jail terms or living under threat of assassination (or both); that the Satgas Papua will go underground and emerge as a kind of youth OPM; that the OPM itself will revert to kidnapping and attacks on resources projects, police and TNI posts, and transmigration settlements on a large scale; and that the PPC peace strategy will be completely derailed. These emerging possibilities and even probabilities show how contingent any peace process is on sensible and humane leadership in Jakarta, which is so obviously lacking. But Jakarta's own opportunities to seize victory through repression-by decisively crushing or cowing the Papuan national movement in whatever form-are now smaller than ever before. This is not only because of the 1997-98 financial collapse and the post-Suharto economic malaise, which have greatly weakened the Indonesian government's domestic and international situation on balance, and not only because the TNI and its security approach to provincial dissidence have been so widely discredited. The international capacity, if not appetite, for forcible intervention against human rights abuse is clearly now a major factor boosting the prospects for Papuan self-determination in the wake of the InterFET (International Force in East Timor) and UNTAET (United Nations Transitional Authority in East Timor) experience in Timor. And Dewan Papua has certainly shown through international moderator Joku (the potential Ramos-Horta of Papua Merdeka) that the international card can be effectively played by the Papuans, even if he himself fell silent in 2001.

Whether the Papua Presidium Council survives or not with its present form and membership, the moral authority of Papuan nationalism is assured by Indonesia's dismal human rights record of the past forty years, the prolonged failure of Jakarta's security-plus-exploitation approach to Papua, and the almost literally mindless contemporary reassertion of the rights of Indonesia Raya. Papuans have not enjoyed any perceptible national gains from their experience within Indonesia, and it is not

130 Franz-Albert Joku, speech at a banquet organized by the Australia West Papua Association, Sydney, June 8, 2001.

131 John Ondawame reply to Franz-Albert Joku, at the banquet organized by the Australia West Papua Association, Sydney, June 8, 2001. However, after the death of Theys Eluay, Ondawame abruptly identified himself with the Presidium for the first time (supporting fellow Amungme, Tom Beanal, the presumptive heir to the chair of the Presidium), and he spoke out in Australia on its behalf. See the report on his remarks ("We [have] lost a great leader, a charismatic leader ... ") at a press conference organized by Action in Solidarity with Asia and the Pacific at Parliament House, Sydney, on November 15, 2001. "Irian Jaya heading for East Timor style crisis," Asia Times Online, November 16, 2001. See also Kabar Irian, November 17, 2001. The stirrings of a rapprochement between OPM and Presidium were plain to see. 
likely that they will take Jakarta's new and fulsome promises concerning their new special autonomy (otonomi khusus—otsus, for short) status seriously.

Otsus, delayed by almost a year, became law for Papua in October 2001. The Papuan governor's draft proposal of a "special autonomy" law, which was forwarded to Jakarta in April after impressive province-wide consultation, had the tacit support of some Presidium members because it self-consciously reproduces much of the Second Papua Kongres's declaration on independence. The team set up by Governor Jap Salossa (who was himself a member of the Team of One Hundred in 1999) proposed the establishment of a Papuans-only upper house; a historical commission to inquire into the legality of Indonesian incorporation in 1963; a provincial veto on military deployments not related to external defense; the right to fly a national flag and display other Papuan symbols; a substantial return of resource revenues to Papua; an autonomous provincial police force under the governor; and, most interestingly for the Presidium, a referendum on independence after five years in the event of otsus failure or a finding by the historical commission that Papua's incorporation into Indonesia did not accord with international law.

The new "special autonomy" law actually passed in Jakarta makes some concessions in all these areas, except the last two (which disappear) and substantial concessions on returning revenues, although the likely impact of these concessions is far from clear. ${ }^{132}$ Yet it cannot be trusted to resolve the Papuan conflict, for "special autonomy" in Indonesia so far is mostly theory, with a bad pedigree of broken promises behind it. More to the point, mass repression is a current reality in Papua; Aceh stands as a grim warning that there may be worse to come; and the murder of Theys Eluay on November 10, 2001 suggests that the TNI may be planning to implement a "final solution" for Papua. The TNI leadership may even be contemplating the burial of otsus itself, since the proposed reforms could conceivably make inroads into their own political, security, and business empire in the region, as well as shrinking central government revenues substantially. ${ }^{133}$

In any case, the surviving Presidium leaders have vehemently declared that the security of Papuans is a far higher priority for them than increased provincial revenues

132 Daniel Cooney, "Indonesia OKs Irian Jaya (sic) Autonomy Bill," Associated Press, October 23, 2001; "A murderous political recipe," Tempo Magazine, 11/II (November 20-26, 2001). The best analysis available so far is by Theo van den Broek. See Special Autonomy: Its Process and Final Contents (Jayapura: Catholic Office for Justice and Peace, December 2001). The key differences between the Papuan draft and the final law are as follows:

While the name "Irian Jaya" at long last gives way to "Papua," symbols conceived as "expressions of identity of the Papuan people" in the governor's draft become "cultural symbols" only in the law.

The Papuan draft awards a "participating role" to the DPRD and governor in security deployments, while the law speaks of a "coordinating function" of the governor only.

The draft proposes a "Commission for the Rectification of Papuan History" under the control of the government of Papua, but the law proposes a "Commission for Truth and Reconciliation" to be set up by the central government after consultation with the governor, whose task is "to provide clarification of Papua's history in order to strengthen the people's unity in the State of the Indonesian Republic."

133 See Peter King, "Indonesia's Hidden Treasure," Australian Financial Review, November 16, 2001. TNI commander for Papua, Mahidin Simbolon, in his best Kopassus disinformation mode, publicly expressed doubt that Theys Eluay had actually been murdered. On TNI and otsus, see also "Military irked by rumors on slain separatist," Laksamana.Net, December 5, 2001. 
or a tripling of the state budget allocation. ${ }^{134}$ Few Papuans have actually benefited from the theoretical swelling of provincial coffers in 2001 under ordinary regional autonomy, and, without far-reaching reform in Indonesia, otsus revenues are unlikely to reach the people in any case. Papuans understand that it is unlikely their region will be "developed" in their lifetimes. (A rise in provincial life expectancy during the 1980s, from the mid-fifties into the low sixties, was surely a product of in-migration.) And if TNI chooses to deal with Papua in the same way it has recently dealt with Aceh and East Timor-the worst extremes of which have not been experienced yet in postreformasi Papua-then many Papuans will die. But Koreri is forever: even in Aceh, there are far more genuine local indigenous adherents of the troubled Indonesian dream than in Papua. Despite the grim threat posed by the Indonesian military, the Papuans will persist in their quest for independence, and the signs are (given Indonesia's parlous current condition) that they will eventually break through, as the East Timorese did. Indonesian civil society must recognize that repressive imperial action against Papua will not save the republic, but only further discredit and weaken it, and make future defection of "naturally" loyal provinces and regions more likely in the long run. Letting go in Papua (and Aceh) could be the beginning of a real solution for Indonesia Raya.

134 "We prefer security to autonomy: Papuan Council," Jakarta Post, November 16, 2001. 
